\title{
Shared Leadership in Commercial Organizations: A Systematic Review of Definitions, Theoretical Frameworks and Organizational Outcomes
}

\begin{tabular}{|c|c|}
\hline Journal: & International Journal of Management Reviews \\
\hline Manuscript ID & IJMR-16-0123.R3 \\
\hline Wiley - Manuscript type: & Original Article \\
\hline Keywords: & shared leadership, distributed leadership, relational leadership \\
\hline $\begin{array}{r}\text { Primary Special Interest Group } \\
\text { (SIG): }\end{array}$ & Leadership and Leadership Development \\
\hline \multirow[t]{2}{*}{$\begin{array}{r}\text { Secondary Special Interest } \\
\text { Group (SIG): }\end{array}$} & Human Resource Management \\
\hline & $\begin{array}{l}\text { The importance of context has been well established in studies of } \\
\text { leadership (Bryman and Stephens 1996; Pettigrew and Whip } \\
\text { 1991). However, recent reviews of shared leadership have tended to } \\
\text { merge findings across commercial and non-commercial settings, } \\
\text { disregarding contextual differences in these distinctive } \\
\text { domains. Acknowledging that the challenges of leadership may vary in } \\
\text { different organizational contexts, this paper argues that a focused review } \\
\text { of shared leadership in commercial organizations is needed. The authors } \\
\text { thus systematically review findings from over twenty years of empirical } \\
\text { research on the practice of shared leadership in commercial organizations, } \\
\text { critically reviewing definitions, theoretical dispositions and measurement } \\
\text { approaches adopted in the field, before evaluating the impact of shared } \\
\text { leadership on performance in this context. Findings from commercial and } \\
\text { non-commercial organizations are then compared, highlighting significant } \\
\text { differences in the conceptualisation of shared leadership in these distinct } \\
\text { settings. Contributing to theory in this field, a framework is developed, } \\
\text { mapping the landscape of current research in commercial contexts, } \\
\text { revealing critical gaps in our present understanding of shared leadership } \\
\text { processes. Consequently, a model summarising a proposed research } \\
\text { agenda for future studies is provided, highlighting the need for such } \\
\text { research to focus on the interactions of individuals as they share in the } \\
\text { leadership of their team. }\end{array}$ \\
\hline
\end{tabular}

\section{SCHOLARONE




\title{
Shared Leadership in Commercial Organizations:
}

\section{A Systematic Review of Definitions, Theoretical Frameworks}

\author{
and Organizational Outcomes
}

\begin{abstract}
The importance of context has been well established in studies of leadership (Bryman and Stephens 1996; Pettigrew and Whip 1991). However, recent reviews of shared leadership have tended to merge findings across commercial and non-commercial settings, disregarding contextual differences in these distinctive domains. Acknowledging that the challenges of leadership may vary in different organizational contexts, this paper argues that a focused review of shared leadership in commercial organizations is needed. The authors thus systematically review findings from over twenty years of empirical research on the practice of shared leadership in commercial organizations, critically reviewing definitions, theoretical dispositions and measurement approaches adopted in the field, before evaluating the impact of shared leadership on performance in this context. Findings from commercial and noncommercial organizations are then compared, highlighting significant differences in the conceptualisation of shared leadership in these distinct settings. Contributing to theory in this field, a framework is developed, mapping the landscape of current research in commercial contexts, revealing critical gaps in our present understanding of shared leadership processes. Consequently, a model summarising a proposed research agenda for future studies is provided, highlighting the need for such research to focus on the interactions of individuals as they share in the leadership of their team.
\end{abstract}

\section{Introduction}

Recent years have seen a growing interest in alternative approaches to leadership, with shared leadership in particular advocated as a way to enable team-based organizations to operate effectively in complex business environments (Burke et al. 2003; Clarke 2018). The increased interest in shared leadership has been stimulated by a number of factors including evolving trends towards team-based structures (Hoch 2013; Salas and Fiore 2004), an increase in knowledge work (Lindkvist 2004), increased complexity (Avolio et al. 2009; Hiller et al. 2006) and the need for continuous organizational change (Higgs 2003; Luscher and Lewis 2008). Added to these contextual factors are changes in societal attitudes to organizations 
generally, featuring increased cynicism regarding the motives of individual business leaders and concerns regarding the leadership capacity of modern organizations (Pearce and Manz 2011).

To deal with these challenges, organizations are increasingly adopting shared approaches to leadership (Hoch 2013; Pearce and Manz 2005). Shared leadership is defined by Conger and Pearce (2003: 1) as 'a dynamic interactive influence process among individuals in groups for which the objective is to lead one another to the achievement of group or organizational goals or both'. Hoch and Dulebohn (2017: 4) describe this as 'the spreading of leadership to multiple or all team members...' Leadership in this form has been described as numerous, transient, fluid, migratory, ambiguous and distributed (Buchanan et al. 2007), representing a significant departure from traditional vertical approaches, where leadership is seen as the remit of formally appointed individuals.

The growing interest in shared leadership has led to a consequent growth in empirical work investigating such approaches, and indeed, such research is timely given the challenges facing organizations described above. However, the blended nature of the emerging empirical literature is problematic for a number of reasons. Firstly, it encompasses many differing conceptualisations of collective forms of leadership, including distributed, shared and emergent leadership, leading to confusion about its definition (Avolio et al. 2009). For clarity, a summary of concepts related to shared leadership is included in Appendix A. A second concern regarding the empirical literature relates to the limited attention given to the selection of appropriate theoretical frameworks underpinning shared leadership studies to date, suggesting the need for improved theorization about the concept (Fitzsimons et al. 
2011). Added to this is a lack of attention to measurement issues and a failure to present a rationale for their use (Conger and Pearce 2003).

Finally, the merging of research from different organizational domains, commercial and noncommercial, fails to recognise important contextual differences across these organization types. According to Locke (2003: 282) 'It should not be assumed that the requirements of leadership in different domains are the same'. Indeed, Locke (2003) specifically states that the leadership needs of the profit-making sector are different to other non-commercial sectors. To date however, the majority of empirical contributions in this field have been located in the educational and healthcare sectors (Bolden 2011). Thorpe et al. (2011: 240) agree, stating that shared approaches to leadership have not been discussed 'anything like clearly enough, except in education'. The concern raised here is that an over-reliance on one sector as the principal source of empirical research may be conceptually limiting our understanding of shared leadership. This paper concurs with calls for context-specific research (Pettigrew 2005; Rashman et al. 2009) to develop our understanding of shared leadership, taking into account factors directly relevant to the specific organizational setting. On this basis, through a systematic literature review, this paper examines existing empirical research on shared leadership in commercial organizational contexts, comparing the evidence with findings from the non-commercial field. To commence, a brief examination of distinguishing features of commercial and non-commercial organizations is presented.

\section{Leadership in Commercial and Non-Commercial Organizations}

A significant body of literature exists comparing private sector, commercial organizations (COs) with public sector and third sector non-commercial organizations (NCOs) (Boyne 2002; Molton and Wise 2010; Perry and Rainey 1988; Rainey and Bozeman 2000). A review 
of the 'public-private difference' literature confirms that such organizations tend to differ in a number of important ways (Nutt 2000). The most frequently cited distinctions are in relation to the organization's ownership and associated funding sources (Boyne 2002; Petrovsky et al. 2014); the nature of the primary goals (Nutt 2000); and influencing forces in the external environment (Boyne 2002; Bozeman 2007). For instance, many authors note that COs are owned by entrepreneurs or shareholders and thus, typically have identifiable owner(s) and private funding arrangements (Andrews et al. 2011). They are driven largely (though not exclusively) by financial goals (Farnham and Horton 1996) and are significantly influenced by external market forces (Boyne 2002). Conversely, broad ownership is an inherent feature of NCOs (Freeman 1984), many of which are funded by taxation (Petrovsky et al. 2014), have multiple, vague goals to provide a public service, or further a social cause (Meier and O'Toole 2006; Solomon 1986), with intangible outcomes (Hartley and Benington 2006). Furthermore, NCOs operating in the public sector are influenced predominantly by political forces, rather than market forces (Aulich 2011). Thus, while COs are typically subject to strong commercial pressures, NCOs normally have few rivals for the provision of their services (Nutt and Backoff 1993).

It is of course acknowledged that not all COs and NCOs conform to all of the characteristics outlined above, and that the level of 'publicness' will vary in different organizations (Bozeman 1987). For instance, many COs pursue environmental goals. Likewise, reform programmes associated with New Public Management (NPM) have seen public sector organizations borrow management approaches from the private sector (Christensen and Laegreid 2017; Hood 1991). However, such approaches have been viewed with scepticism by many in the public administration literature (Ranson and Stewart 1994) and overall, there is an accepted 'continued dissimilarity' between the sectors (Rashman et al. 2009: 465). Thus, 
while 'exceptions abound', empirical findings highlighting differences between these organization types cannot be dismissed (Rainey and Bozeman 2000: 449). According to Fottler (1981: 4), these dissimilarities create 'differences in how the basic functions of management are carried out'. Others concur, citing differences in human resource management practices (Boyne et al. 1999), the management of ethical issues (Berman et al. 1994), decision-making processes (Nutt 2000), managerial values (Metcalf 1989), styles of strategic management (Shortell et al. 1990), levels of organizational commitment (Goulet and Frank 2002), and importantly, leadership styles (Andersen 2010; Bourantas and Papalexandris 1993; Hansen and Villadsen 2010) across these different organization types. For instance, Hansen and Villadsen (2010) found that managers in NCOs (public sector managers) use more participative leadership while managers in COs use more directive leadership. This is consistent with earlier studies claiming that 'private management proceeds much more by direction or the issuance of orders to subordinates by superior managers' (Allison 1979: 462). This suggests that, while many COs (particularly those pursing innovation strategies) have evolved beyond directive leadership, the apparent reluctance to move away from concentrated leadership in some commercial environments remains. This is particularly pronounced in the SME context for instance, where the individual heroic model resonates more with the typical development of an entrepreneur's leadership style (Cope et al. 2011). Such tendencies towards individualistic leadership could constitute a barrier to the adoption of shared approaches in commercial contexts.

Additionally, approaches to accountability and governance structures in COs tend to feature senior managers being held accountable to shareholders for maximizing the bottom line (Mulgan 2000). Such target-based evaluations have been seen to orient leadership towards individualism, rather than collectivism (Currie and Lockett 2011). Boyne (2002) adds that 
this is compounded when managers themselves may have a vested interest in the organizations financial performance, either because they own company shares or their pay is linked to financial performance. Conversely, managers in NCOs are believed to be less materialistic (Metcalf 1989) and less likely to be focused on financial results or motivated by financial rewards (Vigoda-Gadot and Meiri 2008). These differences in managerial values may also impact the leadership approaches facilitated by managers in either context.

Other potential differences stem from a consideration of the factors driving the growth of shared leadership. It is suggested that shared leadership in the public sector has been driven by policy directives advocating shared approaches to leadership as a means of reviving poorly performing public-service organizations (Thorpe et al. 2011). Currie and Lockett (2011: 287) explain that shared leadership is viewed as 'desirable in public services because it is inclusive and...may foster collaborative and ethical practice.' This belief has led government policy, particularly in the UK, to support shared leadership through the implementation of "largescale leadership education initiatives' to orientate public service leaders towards shared approaches (Currie and Lockett 2011: 293). Thus, management in these sectors may be more predisposed to shared approaches to leadership than may be the case in the commercial sector.

Relatedly, Shondrick et al. (2010) caution that shared leadership will be rejected where individuals' implicit leadership theories lack categories for encoding shared leadership behaviours and therefore do not recognize it. Consequently, such individuals may be less inclined to grant or be granted a leadership identity and thus, less likely to influence or be influenced by others (Chrobot-Mason et al. 2016). This builds on O'Toole et al.'s (2002: 251) warning that 'shared leadership for most people is simply counterintuitive'. Given the absence of external driving forces in COs, combined with the prevailing individualistic 
culture of some COs, the question arises as to whether there is a lack of awareness of shared leadership in such contexts. In summary, although COs and NCOs tend to differ in fundamental ways, the shared leadership literature has not distinguished clearly between empirical findings in either context. Failing to account for the differences in organizational context may have led researchers to produce inaccurate generalizations. This paper suggests that the differing characteristics outlined above, combined with the distinct challenges of developing a shared leadership approach in the commercial sector, warrant a focused review of shared leadership developments specific to this domain.

\section{Methodology - Systematic Literature Review}

To identify relevant empirical studies of shared leadership in commercial organizational contexts, the authors carried out a systematic literature review. According to Tranfield et al. (2003: 209), systematic reviews involve exhaustive literature searches of studies, through a 'replicable, scientific and transparent process'. To this end, a review protocol was developed to provide an explicit account of the steps taken and decisions made in selecting literature for this review (see Appendix B). As per the review protocol, the authors developed a keyword search template, confining the search to peer reviewed academic journal articles published since 1995, excluding conceptual and working papers and those relating to shared or distributed leadership in educational, healthcare, religious, political, sporting or other noncommercial contexts. This time period was applied on the basis that the emergence of shared leadership as a distinctive form of organizational leadership is situated in the mid 1990's (Conger and Pearce 2003).

A systematic literature review then followed a sequence of steps utilising five key databases: Business Source Complete, Science Direct, Emerald, ABI Inform and PsychINFO. As many 
authors use the terms 'shared leadership' and 'distributed leadership' interchangeably (Avolio et al. 2009; Ulhoi and Muller 2014) the systematic search targeted sources with either of these terms in the title, abstract and/or key words on the selected databases. This search yielded one hundred and thirty-one (131) articles [excluding duplications] which were then subjected to a staged review, involving an initial reading of the article abstracts, to determine suitability for inclusion (Torraco 2005).

Thus, the abstracts of the 131 retrieved articles were evaluated to assess their relevance to the research objectives and the inclusion/exclusion criteria developed. The inclusion criteria adopted specifically incorporated: qualitative, quantitative and mixed research empirical studies of shared or distributed leadership from 1995 to present, in contextual settings reflecting commercial organizational environments. Following the characteristics described above, commercial organizations were defined simply as organizations seeking to make a profit, while non-commercial organizations were defined as organizations not intending to make a profit.

Student teams simulating organizational environments were included as such contexts have been argued to supply a good venue for studying complex relationships (Mathieu et al. 2015). Moreover, many of the student samples included were business students (e.g. Carte et al. 2006) and researchers have pointed out that 'business students are future business leaders, which may make them appropriate for studies in this domain' (Petersen and Merunka 2014: 1036). Where possible, the nature of student tasks was considered to assess the commercial orientation. In some cases (e.g. Carson et al. 2007: 1225), students were clearly engaged in tasks of a commercial nature, e.g. 'Teams were engaged in real consulting projects and worked closely with their clients over a five-month period that concluded with a significant 
deliverable'. Overall, while the use of student samples is widely debated, the practice still abounds in the social sciences (Bello et al. 2009) and it was deemed important to reveal the extent to which research in this field to date has relied on students as research subjects. For this reason, student samples were included, though in all cases, studies based on student samples are identified as such so that the influence of such samples on this review is transparent. The staged review resulted in the exclusion of ninety-two articles, and the inclusion of thirty-nine articles.

Each article deemed relevant was then subjected to a quality audit, which entailed an inspection of the clarity of the research question, the appropriateness of the methodology and the rigour with which it was employed, the size of the sample selected, the specification of theoretical frameworks and measurement approaches, and the validity of the research findings. While the quality of the journals in which these articles were published was also considered, lower ranking journal articles were not excluded if the article met the quality criteria outlined above. Two articles were excluded from the review at this point (one due to a lack of clarity in the research question posed and one due to insufficient detail regarding the sample studied).

Finally, the systematic database search was supplemented with a manual review which involved hand searching known journals and books, branching out from the studies identified in the electronic database search. This extended the evidence base beyond academic journals to include books published in the field of shared leadership and three further studies were 
included. As an additional quality check, the credentials of book authors ${ }^{1}$ were also checked to ensure the authors were credible sources on the topic. Having completed the systematic database search, the staged review, the quality audit and the manual review, forty studies were finally deemed relevant for inclusion. To ensure a consistent analysis of each study was achieved, an analytical reading (Hart 1998) of the forty studies was carried out, according to a reading guide containing eight pre-defined categories as shown in Table 1 below.

\begin{tabular}{ll}
\hline & Guide for Analytical Reading \\
\hline 1 & Year of publication \\
\hline 2 & Author(s) \\
\hline 3 & Purpose of the study \\
\hline 4 & Definition of shared leadership used \\
\hline 5 & Theoretical framework \\
\hline 6 & Research design/measures \\
\hline 7 & Context/sample \\
\hline 8 & Key findings \\
\hline
\end{tabular}

Table 1: Reading Guide

A summary of the forty empirical studies included in this review is presented in Table 2 (see Appendix C), while the following section discusses the findings of the systematic review in further detail.

\section{Conceptualising Shared Leadership in Commercial Settings}

As Table 2 illustrates, the dominant term used by researchers in commercial organizational contexts to refer to a collective leadership approach, is 'shared leadership', with only one study referring to 'distributed leadership' (Jain and Jeppessen 2014). Comparatively, the term

\footnotetext{
${ }^{1}$ Author credentials were checked by gathering information pertaining to the author's expertise on the topic, including prior publications, education, occupation and the college or university at which the author teaches.
} 
'distributed leadership' is dominant in the educational sector, and to some extent, the healthcare sector also (Bolden, 2011). This is explained by Fitzsimons et al. (2011), who traced the historical origins of shared leadership to developments in the team-based literature, and the emergence of distributed leadership to developments in the education literature.

Considering the studies reviewed in Table 2, researchers display a wide variety of interpretations of 'shared leadership', with little commonality at first glance. For instance, some view shared leadership in functional terms, describing it as 'the sharing of leadership roles, responsibilities and functions...' (Acar 2010: 1740) while others adopt a more relational perspective, viewing it as 'a collective, social influence process...' (Hoch et al. 2010: 105). A further analysis reveals that there are indeed alternative views on how shared leadership is conceptualised in commercial settings. Firstly, considering the source of leadership, the majority of researchers in the studies reviewed, state that shared leadership originates internally, within the team or work unit (e.g. Mathieu et al. 2015). However, not all researchers see this as a defining feature (e.g. Chreim 2015) and have included external leaders in conceptualisations of shared leadership. Also, differences arise when considering the degree of formal authority pertaining to shared leadership. While a minority of studies have examined shared leadership behaviours in formal leadership roles (e.g. Mehra et al. 2006; Patton and Higgs 2013), most researchers have assumed that shared leadership is informal involving an exchange of lateral influence among peers (Pearce and Sims 2002) in non-hierarchical relationships (Liu et al. 2014). Others refer to the emergent nature of shared leadership as a core characteristic of the concept, suggesting that it occurs in a way that is not pre-planned (Carson et al. 2007). Thus, while operating in a formal leadership role does not preclude one from sharing leadership responsibilities, most of the studies reviewed 
conceptualise shared leadership as the informal spreading of leadership across the members of a team (Hoch and Dulebohn 2017).

The definitions reviewed also provide an insight into the researchers' expectations of the outcomes of shared leadership. While some researchers refer to the implementation of change (Waldersee and Eagleson 2002) and the motivation of team members (Gupta et al. 2011) as expected outcomes, the majority of researchers convey the more generic expectation that shared leadership will lead to goal accomplishment (e.g. Hoch et al. 2010; Muethal et al. 2012). This is consistent with the conventional leadership literature where leadership theories commonly identify goal attainment as an expected outcome of leadership (Northouse 2001).

One dimension, which most researchers agree on, is the temporal nature of shared leadership, highlighting 'time as a core aspect of the phenomenon' (D'Innocenzo et al. 2014: 5). This is reflected most prominently in Conger and Pearce's (2003: 1) definition of shared leadership as 'a dynamic, interactive, influence process...', which was adopted by a number of researchers in the empirical work analysed (e.g. Hoch 2013; Zhou et al. 2015). The temporal quality inherent in this definition suggests that shared leadership is not static (Friedrich et al. 2011) but changes over time when different members of an organizational unit may assume leadership roles at various points during the team's life-cycle (Erez et al. 2002). Given the dynamic nature of most commercial settings, this is likely to be an important characteristic. However, of the forty studies reviewed, only five adopted a longitudinal approach (Acar 2010; Carte et al. 2006; Drescher et al. 2014; Mathieu et al. 2015; Small and Rentsch 2010) raising methodological concerns regarding studies of shared leadership, as cross-sectional approaches may not be capturing an important aspect of the phenomenon under investigation. 
Overall, while inconsistencies in the definitions adopted are apparent, most studies reviewed broadly conceptualise shared leadership as the lateral influence of organizational peers on each other in the pursuit of goals. While progress has been made in this regard however, it is considered that shared leadership is still a relatively 'primitive term' (Pearce et al. 2007: 286) which would benefit from further empirical and theoretical work to define the concept more precisely (Park and Kwon 2013).

\section{Dominant Theoretical Frameworks and Measurement Approaches}

To evaluate developments in the field of shared leadership, it is important to consider the dominant theoretical frameworks and measurement approaches employed by researchers in their empirical work to date. The following table (Table 3) presents a summary of the principal theoretical frameworks and measurement approaches adopted by the studies included in this review.

\begin{tabular}{llll}
\hline $\begin{array}{l}\text { Theoretical } \\
\text { Frameworks }\end{array}$ & $\begin{array}{l}\text { Measurement } \\
\text { Approaches }\end{array}$ & $\begin{array}{l}\text { Samples: } \\
\text { Non-student v student }\end{array}$ & $\begin{array}{l}\text { Temporal } \\
\text { Nature }\end{array}$ \\
\hline & & & \\
15 Aggregation $^{2}(38 \%)$ & 29 Quantitative (73\%) & 25 Non-student samples (62\%) & 35 Cross-sectional (88\%) \\
13 Social network theory (32\%) & $\begin{array}{c}\text { 10 Qualitative (25\%) } \\
\text { 1 Mixed methods (2\%) }\end{array}$ & & 15 Student samples (38\%) \\
$\begin{array}{l}\text { 5 Others (13\%) } \\
\text { 7 Not identified (17\%) }\end{array}$ & & & \\
\hline
\end{tabular}

Table 3 - Summary of Theoretical Frameworks and Measurement Approaches

\footnotetext{
${ }^{2}$ While aggregation is a measurement technique and not a theory per se, it has been used in the shared leadership literature (e.g. D’Innocenzo et al. 2014) to describe a theoretically distinct approach to the conceptualisation of shared leadership as the sum of the overall leadership provided by members of a group.
} 
The dominant theoretical frameworks and measurement approaches identified in Table 3 are now considered in order to understand how they have framed the empirical research in this area.

\section{Aggregation}

The Oxford English dictionary defines aggregation as a whole formed by combining several separate elements. The majority of studies in this review (38\%) employed aggregation approaches to research shared leadership (e.g. Fausing et al. 2015), conceptualising shared leadership as a team-level construct, i.e. each individual measures what the 'team as a whole' performs in terms of leadership. This approach to measuring shared leadership is consistent with recommendations by Tesluk et al. (1997) who suggest that group level phenomena can be measured by having each individual rate the group on attributes defined at the group level.

Of the studies adopting an aggregation approach, the most popular measures utilised were aggregated behavioural scales for five leadership strategies, including aversive, directive, transactional, transformational and empowering (e.g. Hoch et al. 2010). Other studies (e.g. Avolio et al. 1996) used modified traditional leadership items (such as the Multifactor Leadership Questionnaire) to assess leadership from the team as a whole, rather than from individuals. An alternative approach was employed by Boies et al. (2010), who measured instances of transformational and passive avoidant leadership evident at the team level. Thus, while there is a consistent use of aggregation approaches in researching shared leadership, there appears to be a lack of consistency in terms of what specific measurements should be aggregated, raising the question as to whether researchers have sufficiently developed an understanding of what it is they are measuring (Fausing et al. 2015). 
While the aggregation approach has remained popular, some authors are critical of such 'minimalist' approaches, suggesting that shared leadership is more complex than the sum of the overall leadership provided by group members (D’Innocenzo et al. 2014; Gronn 2002). Wang et al. (2014: 185) explain that the unique relationships between team members are obscured using such an approach which can 'smooth the differences in contributions of each individual member'. Other criticisms assert that studies employing such approaches have adopted inherently vertical leadership themes, such as transactional, directive and empowering leadership (D'Innocenzo 2014), all of which imply a vertical leader-follower relationship (Pearce and Manz 2005). D'innocenzo et al. (2014) question whether such leadership theories are adequate to explain instances of leadership outside of downward leadership influence, suggesting that shared leaders who do not have the formal authority to lead (Hollander and Offermann, 1990) may lead in different ways.

An alternative theoretical approach to researching shared leadership is employed by others, incorporating the network of influencing relationships within a team. While this has not been employed as frequently as the aggregation approach (32\% of studies reviewed), the social network approach is growing in popularity.

\section{Social Network Theory}

As shared leadership is a relational phenomenon, social network theory is considered an appropriate approach for studying it, allowing the relationship among individuals to be emphasised as the unit of analysis (Sparrowe et al. 2001). Essentially, the network approach requires each team member to rate all other team members in terms of their respective leadership influence. According to Yukl (1989), this allows leadership to be studied as a shared activity, incorporating the reciprocal influence processes among multiple members of a 
group. The primary disadvantage of this approach, is that it is 'quite burdensome on participants' and the methods are somewhat complex (Conger and Pearce 2003: 298).

Two distinct social network measures have been adopted in the studies analysed in this review, namely; density (e.g. Mathieu et al. 2015) and centralization (e.g. Mehra et al. 2006). The density of a network is defined as the proportion of possible links that are actually present in the network (Wasserman and Faust 1994) or the mean number of ties (relationships) per group member (Sparrowe et al. 2001). Carson et al. (2007: 1220) explain that ties exist 'when one team member perceives another as exerting leadership influence in the team'. Centralization refers to an approach whereby the most influential person in a network is identified as prominent and a network centralization measure is calculated by measuring the sum of differences in centrality between the most central node in the network and all other nodes. D'Innocenzo et al. (2014) suggest that conceptualizing shared leadership in this way will yield a more informative measure than overall team ratings (aggregation).

While the theoretical frameworks discussed here have provided researchers with the tools to identify the extent to which shared leadership is occurring (aggregation) and where in the work unit the leadership influence is located (social network theory), it is suggested that they may not satisfactorily reveal the nature of the 'dynamic interactive influence process...' referred to by Conger and Pearce (2003: 1) and that a more sophisticated approach is required (Locke 2003). This paper suggests that a research framework is needed which enables researchers to study the underlying interactions between individuals sharing leadership responsibilities, to develop a deeper understanding of how members share leadership within a group setting, and how this evolves over time. 


\section{Measurement Approaches}

In addition to concerns regarding theoretical frameworks, some concerns also arise in relation to measurement practices employed in shared leadership research to date. As illustrated in Table 3, many of the studies reviewed (38\%) rely on the analysis of data drawn from student samples. This is not unusual in social science research. However, it raises questions about the extent to which these findings can be generalized to other (non-student) situations. According to Peterson (2001), effect sizes from student samples can differ from those of nonstudent samples in terms of direction and magnitude. Reflecting concerns regarding the use of student samples, this paper supports calls for future empirical studies of shared leadership to be located in authentic organizational settings. For the purpose of this review, studies using student samples are identified as such, and where possible, findings in relation to student versus non-student samples are highlighted.

A further concern relates to the methodological choices made by researchers in the studies reviewed. The majority of studies in this review (73\%) relied on quantitative research designs suggesting that the dominant epistemological position within this field to date has been positivist. This reflects Serban and Roberts (2016: 195) recent comments that shared leadership as a research area 'remains largely a quantitative domain'. Adopting Grint's (2000) perspective, this paper concurs with the view that leadership is primarily a social phenomenon that relies on the subjective interpretations of followers and thus an interpretive epistemological position is needed to complement the quantitative work in the field. A final concern in this regard is the cross-sectional nature of the research designs in the studies reviewed (88\%), which ultimately fail to accommodate the dynamic nature of shared leadership, resulting in an inability to adequately capture issues such as direction and causality between the variables studied (Fausing et al. 2013). Given the dynamic nature of 
the modern commercial workplace, this is a considerable weakness in the current body of research. To address these issues, this paper concurs with calls for future research to adopt longitudinal, qualitative approaches to explore shared leadership interactions over time in different contexts (Hildebrand et al. 2012; Hoch and Dulebohn 2013).

\section{Framework of Current Research}

Having discussed conceptual definitions, theoretical frameworks and measurement approaches, this paper now synthesizes the empirical evidence reviewed in relation to factors influencing the emergence of shared leadership in commercial organizations, and the impact of shared leadership on performance in such contexts. These findings have been elicited from the forty empirical studies identified in the systematic literature review described earlier. Preceding the discussion, the following framework (Fig. 1) provides an illustration of the findings in this regard. Each factor identified in the framework is discussed further below. 


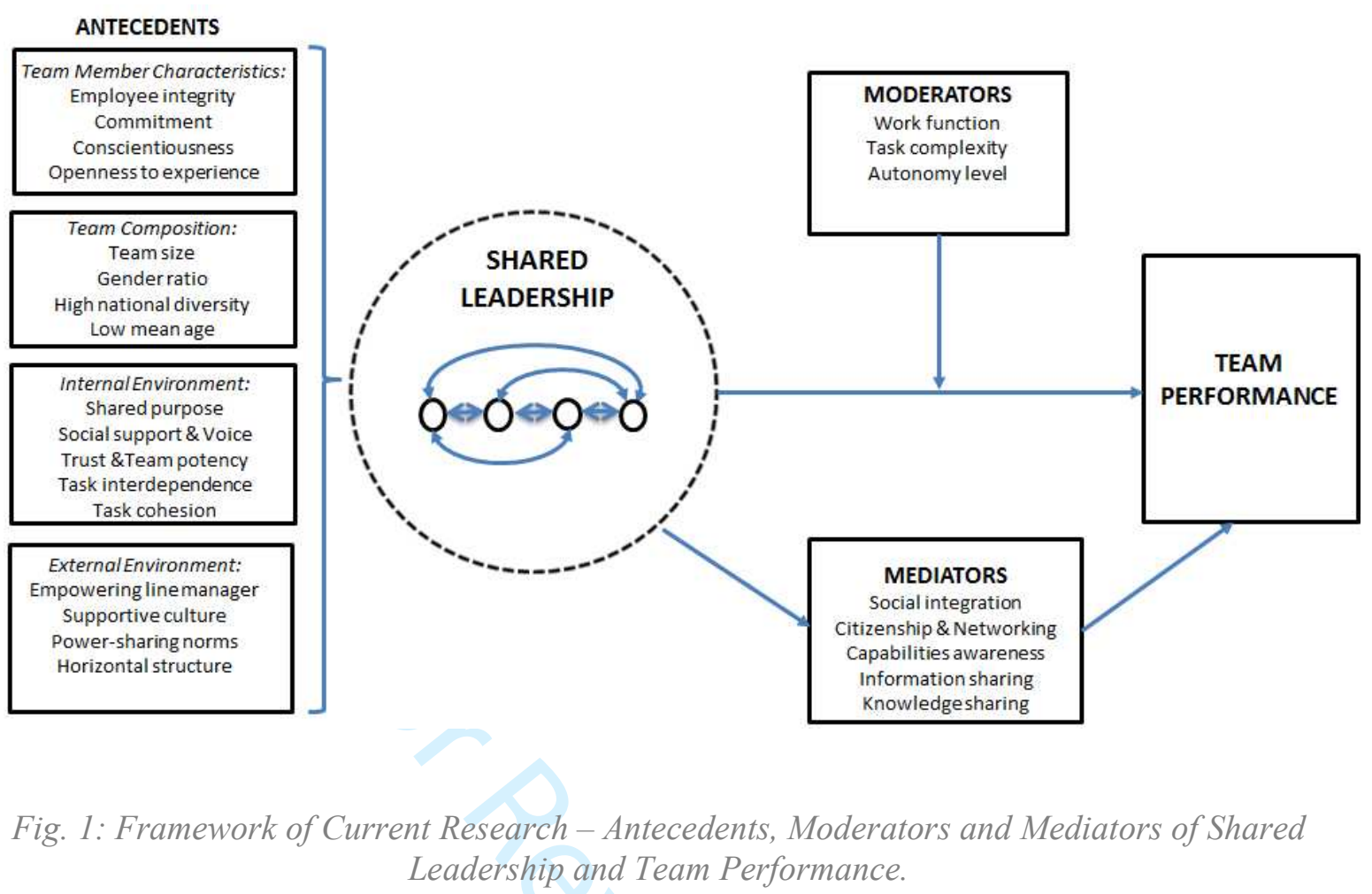

\section{Antecedent Conditions for Developing Shared Leadership}

Only eleven of the forty studies reviewed explored antecedent conditions to any extent, identifying factors relating to employee characteristics, team composition, and the internal and external team environment as influential in shared leadership emergence. Considering employee characteristics, Hoch (2014) reports that team member integrity (integrity is equated with responsibility and trustworthiness in the study) functions as an antecedent of shared leadership, while others identify employee commitment and professionalism as important employee traits (Jain and Jeppesen 2014). Zhou and Vredenburgh (2017) recently expanded on this, concluding that conscientiousness and openness to experience are positively related to shared leadership emergence in entrepreneurial teams.

Focusing more on team composition, others report that the socio-demographic characteristics of teams significantly influence the emergence of shared leadership behaviours, concluding 
that shared leadership is more likely to emerge in teams featuring a high female-to-male ratio, high levels of national diversity and a low mean age (Muethel et al. 2012). The first characteristic, they suggest, is explained by behavioural leadership notions that women prefer participative leadership styles (Northouse 2001), though this finding is in contrast to others who found that shared leadership has no significant effect on female participation in leadership roles (Mendez and Busenbark 2015). In relation to national diversity, Muethel et al. (2012) suggest that the availability of diverse knowledge and experience fosters a shared approach to decision-making and is thus likely to facilitate the emergence of shared leadership. Finally, the researchers report that a high mean age does not support shared leadership, implying that younger members are more likely to engage in shared leadership behaviours (Muethel et al. 2012).

In relation to team size, the evidence is less clear as variations in team size in existing studies makes it difficult to ascertain its effects on shared leadership emergence (D’Innocenzo, 2014). Some researchers have indicated that team size can be both an asset and a liability for teams (Carson et al. 2007; Huang 2013). This is reflective of the wider literature which is also inconclusive on this issue. For instance, some authors suggest that larger teams could have a positive impact on shared leadership due to increased decision making and information processing capabilities (Hill 1982; Maier 1967). However, others have found that in general, members of larger teams are less satisfied, and cooperate less than members of smaller teams (Guzzo et al. 1995). Pearce and Herbik (2004: 296) explain that 'With increases in team size, the psychological distance between individuals can increase'. The implication here is that in larger teams, members would be less likely to exhibit shared leadership as the psychological distance between team members increases. Clearly, further research is required to clarify the impact of team size on shared leadership emergence. 
Referring to the internal team environment, researchers report that shared leadership is facilitated when the three conditions of shared purpose, social support, and voice are present in the team environment (Carson et al. 2007; Daspit et al. 2013). In addition, Fausing et al. (2015) explain that task interdependence increases team cooperative behaviours and is positively related to shared leadership emergence. This concurs with other views that 'shared leadership is applicable only to tasks where there is interdependency between the individuals involved (Wassenaar and Pearce 2012: 382). The implication here is that the opportunity for shared leadership decreases, as tasks become more independent (Pearce and Sims 2000). Extending these findings, Serban and Roberts (2016: 184) add that task cohesion, which they define as 'a group's shared attraction and commitment to the group goal' is also a predictor of shared leadership, in a creative task context. Others explored trust, team collectivism (Small and Rentsch 2010) and team potency (Boies et al. 2010) as antecedents of shared leadership, concluding that all of these conditions contribute to its emergence.

In relation to the external team environment a number of authors identify the need for empowering behaviours from vertical leaders as an antecedent (Carson et al. 2007; Fausing et al. 2015). This confirms views in the literature that empowering vertical leadership is a key condition required for shared leadership to develop (Clarke 2012). Others identify a supportive culture (Erkutlu 2012) along with organizational conditions of power sharing and a horizontal structure (Jain and Jeppesen 2014) as important pre-conditions to the successful development of shared leadership approaches.

While the studies reviewed here make important contributions to our understanding of the conditions facilitating the emergence of shared leadership in COs, more studies are needed. 
For instance, while Hoch (2014) identifies the influence of employee integrity on the emergence of shared leadership, other potentially important employee variables have yet to be explored (e.g. locus of control, tenure, expertise). Likewise, in the broader organizational environment, interventions such as training programmes which focus on mutual skill development (Wood 2005) or the availability of financial rewards or recognition (Serban and Roberts 2016) could influence the emergence of shared leadership but are untested. Furthermore, the impact of national or organizational culture on shaping the behaviours of individuals in relation to shared leadership may be important. It is noted that the studies reviewed here are derived from a diverse range of national cultures and sectors, which may have an impact on the findings, but this has not been explained by research to date. Further studies in relation to the impact of culture on shared leadership emergence would be useful to extend the research in this regard. Finally, the studies reviewed here have focused on identifying antecedent conditions in the internal organizational environment, neglecting external environmental forces.

\section{Evaluating the Outcomes of Shared Leadership}

To date, the research on shared leadership in COs has focused primarily on outcomes in terms of team performance and effectiveness. According to Campbell et al. (1993) performance refers to actions or behaviours that can be measured in terms of the team's contribution to the organization's goals. Effectiveness on the other hand is the capacity a team has to accomplish its goals (Hackman, 1987). In relation to both of these outcomes, the findings in the shared leadership literature are largely positive (Nicolaides et al. 2014; Wang et al. 2014). 


\section{Outcomes of Shared Leadership - Team Performance}

Of the forty empirical studies reviewed, twenty-three measured the impact of shared leadership on performance. Of these twenty-three studies, nineteen (83\%) conclude that shared leadership provided by team members can contribute significantly to team performance (e.g. Carson et al. 2007; Pearce and Ensley 2001). Given the concerns raised earlier in relation to the use of student samples, the authors further isolated results from studies using student samples to compare with findings from studies using non-student samples, in relation to the impact of shared leadership on team performance. The following table (Table 4) summarises the results.

\begin{tabular}{llll}
\hline Sample & $\begin{array}{l}\text { No. of studies measuring } \\
\text { performance impact of } \\
\text { SL }\end{array}$ & $\begin{array}{l}\text { No. of studies reporting } \\
\text { positive impact on } \\
\text { performance }\end{array}$ & $\begin{array}{l}\text { \% of studies } \\
\text { reporting } \\
\text { positive impact } \\
\text { on performance }\end{array}$ \\
\hline $\begin{array}{l}\text { Combined (non-student } \\
\text { plus student samples) }\end{array}$ & 23 & 19 & $83 \%$ \\
\hline Non-student samples only & 14 & 12 & $86 \%$ \\
\hline Student samples only & 9 & 7 & $78 \%$ \\
\hline
\end{tabular}

Table 4 - Impact of Shared Leadership on Team Performance by Sample Type

Table 4 illustrates that the majority of studies reviewed, regardless of the sample type, report that shared leadership has a positive impact on team performance. This is not meant to imply that concerns about student samples are not warranted however and conceding that such practice can result in concerns regarding external validity (Bello et al. 2009), the authors have suggested earlier that future studies of shared leadership should comprise non-student samples in authentic organizational settings.

In short, the evidence reviewed suggests that where teams relied on multiple members for leadership, performance improved (Carson et al. 2007). An early study by Avolio et al. 
(1996) explains that shared leadership is significantly related to team members' willingness to put in extra effort on projects, and thus, has a positive impact on team performance. Pearce and Sims (2002) concur, explaining that shared leadership is significantly related to increased citizenship and networking behaviours, both of which impact performance. Others suggest that shared leadership is actually a better predictor of team performance than vertical leadership (Ensley et al. 2006; Hoch and Kozlowski 2014) explaining for instance that shared leadership accounts for a greater occurrence of social integration and problem-solving quality, and is more effective at implementing change, than leadership exhibited by a single appointed leader (Waldersee and Eagleson 2002). Additionally, researchers report that shared leadership is a more important predictor of new venture performance in entrepreneurial teams, than vertical leadership (Ensley et al. 2006; Zhou et al. 2015). These results are consistent with recent meta-analytic studies in the field which conclude that shared leadership effects performance over and above the effects of vertical leadership (Nicolaides et al. 2014; Wang et al. 2014).

While these findings are encouraging however, others add a note of caution (Fausing et al. 2013; Serban and Roberts 2016) suggesting that the positive relationship between shared leadership and team performance is not necessarily straightforward. Chreim (2015: 538) for instance warns that, sharing leadership roles can be disadvantageous when it creates an 'overcrowded leadership space' where role overlap can result in redundant effort. Importantly, Fausing et al. (2013) indicate that, while knowledge-intensive teams benefit from sharing leadership, such an approach may negatively affect manufacturing team performance. Furthermore, the authors conclude that sharing leadership is a performance disadvantage in teams with low levels of autonomy. Thus, despite the predominantly positive 
findings reported by many researchers, it is important to note that shared leadership may not always be effective and advantageous' (Fausing et al. 2013: 256).

\section{Outcomes of Shared Leadership - Team Effectiveness}

The research studies reviewed here also report positive outcomes in relation to shared leadership and team effectiveness. For instance, researchers have found that shared leadership is positively related to team creativity (Lee et al. 2015) and team learning (Huang 2013). Furthermore, teams with shared leadership approaches experience less conflict, greater consensus and higher intragroup trust and cohesion (Bergman et al. 2012; Mathieu et al. 2015). Moreover, such teams exhibit an advanced awareness of team member capabilities and excel at the effective utilisation of their members (Ocker et al. 2011). Finally, Acar (2010) reports that shared leadership moderates the relationship between diversity and emotional conflict, rendering groups more effective as a result.

Certainly, the outcomes reported here are encouraging for COs. However, more research is needed to understand how shared leadership impacts team performance and effectiveness in commercial settings. Drawing on the literature reviewed, the following section identifies specific moderators and mediators of the relationship between shared leadership and team performance, in order to examine these relationships in further detail.

\section{Moderators and Mediators of Shared Leadership and Team Performance}

The empirical studies reviewed have revealed a number of moderators in the relationship between shared leadership and performance, including work function, levels of work autonomy (Fausing et al. 2013); and task complexity (Hoch 2014; Wang et al. 2014). As described above, while shared leadership exhibited a positive relationship with team 
performance for knowledge-intensive teams, it exhibited a negative relationship for manufacturing teams (Fausing et al. 2013). Similarly, team autonomy was confirmed as a moderator by Fausing et al. (2013) who concluded that sharing leadership is a performance disadvantage in teams with low levels of autonomy. An earlier study by Hoch et al. (2010) concluded that where tasks are routine, shared leadership does not impact team performance. Others agree that the effects of shared leadership are stronger when work is more complex (Wang et al. 2014). These findings are significant implying that the likely success of shared leadership in a commercial context is contingent on the nature of the work, the level of task complexity, and the level of employee autonomy.

In relation to mediators, specific contributions from the literature have identified knowledge sharing (Huang 2013) and information sharing (Hoch 2014) as mediating variables in the relationship between shared leadership and team performance. Other mediating factors reported include improved social integration of team members (Avolio et al. 1996); increased citizenship and networking behaviours (Pearce and Sims 2002); increased awareness of team member capabilities (Ocker et al. 2011); greater consensus, less conflict, higher intra group trust and better team cohesion (Bergman et al. 2012).

While the studies reviewed here have contributed to an understanding of the relationship between shared leadership and performance, some limitations must be noted. In many of the studies, a stated limitation is the lack of control for the effects of other variables, which may have affected the relationship between shared leadership and performance, such as the experience, ability and motivation of team members, as well as other dimensions of team composition. Thus, further research is required to expand our understanding of these relationships. 


\section{Practical Contributions and Limitations of the Framework}

The evidence from this review suggests that shared leadership has the potential to address the leadership challenges faced by commercial organizations discussed earlier. For instance, while increased levels of diversity and complexity in the modern workplace pose challenges for traditional leadership models, the same conditions are highly compatible with shared approaches to leadership. Similarly, concerns regarding the lack of leadership capacity in modern organizations (Pearce and Manz 2011) could be addressed by tapping into the leadership potential distributed among knowledgeable organizational members outside of the management hierarchy. It is not suggested however that shared leadership should replace vertical leadership, rather that it can complement the presence of an empowering line manager, enabling knowledgeable group members to contribute to the leadership of their group when there are opportunities to do so. It is also recognised that a contingency approach to the application of shared leadership should be adopted, as this review has shown that sharing leadership in COs is ineffective in some situations, for instance where tasks are routine (Hoch 2014) or where employees have low autonomy (Fausing et al. 2013).

Thus, Figure 1 is offered as a proposed framework which commercial organizations can consult to encourage shared approaches to leadership to emerge, where appropriate. For instance, in knowledge-intensive teams where employees have high autonomy, managers could encourage shared leadership to emerge by making decisions about employee selection and team composition which are cognisant of the antecedents discussed above. Additionally, managers wishing to encourage shared leadership in practice could ensure interdependence in the design of tasks, for example by providing the team with tasks or goals that can only be reached through collaboration. This is not to suggest that collaboration within teams equates 
with shared leadership; rather that teams that collaborate in their work are more likely to influence each other in ways that can lead to the accomplishment of group or organizational goals. It is this active influence which distinguishes shared leadership from other team processes such as teamwork, collaboration, or self-management (Carson et al. 2007). Finally, managers should endeavour to influence the broader conditions that facilitate the emergence of shared leadership by adopting empowering managerial approaches, distributed power sharing structures and supportive organizational cultures.

Some limitations of the framework must be noted at this point. It has been observed earlier that there are subtle differences in how shared leadership has been conceptualised and measured in the empirical studies reviewed. In order to portray the overall landscape of current research, this framework synthesizes the findings from these reviews, which to some extent suggests a unitary representation of shared leadership. It is not the authors' intent to suggest that there is a single "correct" definition or consensus about what constitutes shared leadership. Indeed, it has already been noted above that shared leadership is still considered a relatively 'primitive term' by some (Pearce et al. 2007: 286). Nonetheless, the authors have observed that the studies analysed all characterise shared leadership as the active influence of organizational members on each other in the pursuit of organizational or team goals, and from a pragmatic perspective, integrating the findings in such a framework contributes to an overall understanding of progress in the field so far.

A further limitation may arise in the application of the framework to non-team based COs. While most of the studies reviewed here refer to settings where team membership was relatively clear, in many COs, this may not be the case and it is not clear how shared leadership could be facilitated in such circumstances. Even in organizations with team-based 
structures, team membership may be ambiguous or transient, and it is not clear how this might impact the practice of shared leadership. Indeed, where knowledge is widely dispersed, it may be necessary to share leadership across team boundaries, but research to date has not explored these scenarios. Undoubtedly, further research is required to develop this field of study further.

\section{Comparisons with Other Settings}

To explore the assertions made earlier regarding the importance of context, it is useful to consider the review findings in relation to evidence from NCOs. To this end, findings from studies of shared leadership in NCOs were reviewed. The studies in NCOs were selected by referring to the systematic literature review carried out earlier, to identify those studies that were excluded on the basis that they were located in the non-commercial sector. Any studies in NCOs that referred to antecedents, moderators, mediators or outcomes of shared or distributed leadership were thus selected for comparison purposes. This yielded twenty-three studies of shared leadership in NCOs, primarily incorporating healthcare, educational and religious organizations. A further breakdown on the nature of the NCOs studied is shown in Appendix D. Preceding a discussion of the notable comparisons, Table 5 below presents a summary view, comparing the findings from empirical studies of shared leadership in COs, with those in NCOs. 


\begin{tabular}{|c|c|c|c|}
\hline Themes & $\begin{array}{l}\text { Commercial organizations } \\
\text { (COs) }\end{array}$ & Non-commercial Organizations (NCOs) & $\begin{array}{l}\text { Notable } \\
\text { Comparisons }\end{array}$ \\
\hline $\begin{array}{l}\text { Focus of } \\
\text { empirical } \\
\text { research }\end{array}$ & $\begin{array}{l}\text { Teams and team performance } \\
\text { (Ulhoi and Muller, 2014). }\end{array}$ & $\begin{array}{l}\text { Health - organizational change, org } \\
\text { development, processes surrounding } \\
\text { implementation of SL. } \\
\text { Education - new org structures; new ways } \\
\text { of organizing; learning through collective } \\
\text { ways of leading (Ulhoi and Muller, 2014). }\end{array}$ & $\begin{array}{l}\text { Broader, institutional } \\
\text { focus in NCOs. }\end{array}$ \\
\hline Concept of SL & $\begin{array}{l}\text { Predominantly informal, } \\
\text { lateral influence among peers } \\
\text { (Pearce and Sims 2002). }\end{array}$ & $\begin{array}{l}\text { Formal and informal - leadership practice } \\
\text { stretched across formal leaders, followers } \\
\text { and the situation (Spillane et al. 2004). }\end{array}$ & $\begin{array}{l}\text { More planned and } \\
\text { integrated approach } \\
\text { in NCOs. Limited } \\
\text { evidence regarding } \\
\text { interplay between } \\
\text { vertical leadership } \\
\text { (VL) and SL in COs. }\end{array}$ \\
\hline Mechanisms & $\begin{array}{l}\text { Lateral influence (Pearce and } \\
\text { Sims 2002), interaction of } \\
\text { team members (Wang et al. } \\
\text { 2014). }\end{array}$ & $\begin{array}{l}\text { Interdependence - reciprocal, pooled and } \\
\text { sequential (Spillane et al. 2004); } \\
\text { dynamic delegation (Klein et al. 2006); } \\
\text { processes of inter-individual exchange or } \\
\text { collaborative interaction (networking, } \\
\text { collaborating \& knowledge-sharing), } \\
\text { (Buchanan et al. 2007); continuous } \\
\text { education/training in SL (Jackson 2000). }\end{array}$ & $\begin{array}{l}\text { Few insights into } \\
\text { mechanisms } \\
\text { underlying SL in } \\
\text { COs. }\end{array}$ \\
\hline
\end{tabular}

\begin{tabular}{|c|c|c|c|}
\hline Antecedents & & & \\
\hline $\begin{array}{l}\text { Employee } \\
\text { characteristics: }\end{array}$ & $\begin{array}{l}\text { Employee commitment (Jain } \\
\text { and Jeppesen 2014); integrity } \\
\text { (Hoch 2014); } \\
\text { conscientiousness, openness } \\
\text { to experience (Zhou and } \\
\text { Vredenburgh 2017). }\end{array}$ & $\begin{array}{l}\text { Employee commitment and commitment to } \\
\text { SL principles (internalisation of SL } \\
\text { concepts) (Jackson 2000). }\end{array}$ & $\begin{array}{l}\text { Limited evidence of } \\
\text { employee } \\
\text { characteristics } \\
\text { facilitating SL in } \\
\text { NCOs. More } \\
\text { progress in COs in } \\
\text { this regard. }\end{array}$ \\
\hline $\begin{array}{l}\text { Team } \\
\text { composition: }\end{array}$ & $\begin{array}{l}\text { High national diversity; low } \\
\text { mean age; high female to } \\
\text { male gender ratio (Muethel et } \\
\text { al. 2012). }\end{array}$ & $\begin{array}{l}\text { Inclusion, diversity (Slantcheva-Durst } \\
\text { 2014), representation of diverse } \\
\text { constituencies (Eckel and Kezar 2003). }\end{array}$ & $\begin{array}{l}\text { Subtle differences in } \\
\text { conceptualization of a } \\
\text { team. Broader range } \\
\text { of stakeholders } \\
\text { considered in NCOs. }\end{array}$ \\
\hline $\begin{array}{l}\text { Internal team } \\
\text { environment: }\end{array}$ & $\begin{array}{l}\text { Shared purpose, social } \\
\text { support, voice (Carson et al. } \\
\text { 2007); trust (Small and } \\
\text { Rentsch 2010); team potency } \\
\text { (Boies et al. 2010); task } \\
\text { interdependence (Fausing et } \\
\text { al, 2015); task cohesion } \\
\text { (Serban and Roberts 2016). }\end{array}$ & $\begin{array}{l}\text { Social harmony, team affinity, shared goals } \\
\text { (Jackson 2000); team identity, voice } \\
\text { (Slantcheva-Durst 2014); trust (Eckel and } \\
\text { Kezar, 2003; James et al. 2007; Greenfield } \\
\text { et al 2009); interdependence (Spillane et al. } \\
\text { 2004). }\end{array}$ & $\begin{array}{l}\text { Similar antecedents } \\
\text { in the internal team } \\
\text { environment in both } \\
\text { COs and NCOs - } \\
\text { importance of shared } \\
\text { goals and } \\
\text { interdependence. }\end{array}$ \\
\hline $\begin{array}{l}\text { External team } \\
\text { environment: }\end{array}$ & $\begin{array}{l}\text { Empowering managers (Hoch } \\
\text { 2014; Fausing et al. 2015); } \\
\text { supportive culture (Erkutlu } \\
\text { 2012); power-sharing norms } \\
\text { and horizontal structure (Jain } \\
\text { and Jeppesen 2014). }\end{array}$ & $\begin{array}{l}\text { Empowerment, sharing culture, team-based } \\
\text { structures \& processes (Slantcheva-Durst } \\
\text { 2014); management support for SL, } \\
\text { collaborative structures (Jackson 2000); } \\
\text { supportive culture (Wood 2005); } \\
\text { permission to select partnerships } \\
\text { (Greenfield } \text { et al. 2009). }\end{array}$ & $\begin{array}{l}\text { Similar antecedents } \\
\text { in external team } \\
\text { environment in both } \\
\text { COs and NCOs. } \\
\text { Importance of } \\
\text { empowering } \\
\text { managers. }\end{array}$ \\
\hline
\end{tabular}




\begin{tabular}{|c|c|c|c|}
\hline Themes & $\begin{array}{l}\text { Commercial Organizations } \\
\text { (COs) }\end{array}$ & Non-commercial Organizations (NCOs) & $\begin{array}{l}\text { Notable } \\
\text { Comparisons }\end{array}$ \\
\hline $\begin{array}{l}\text { External } \\
\text { organizational } \\
\text { environment: }\end{array}$ & No evidence from COs. & $\begin{array}{l}\text { Supportive government policies and } \\
\text { initiatives, low regulatory pressures for } \\
\text { performance, high levels of social affluence } \\
\text { (Currie \& Lockett 2011). }\end{array}$ & $\begin{array}{l}\text { Lack of evidence } \\
\text { regarding how factors } \\
\text { in the external } \\
\text { micro/macro } \\
\text { environment impact } \\
\text { SL in COs. }\end{array}$ \\
\hline Moderators & $\begin{array}{l}\text { Work function, autonomy } \\
\text { level (Fausing et al. 2013); } \\
\text { task complexity (Hoch 2014, } \\
\text { Wang et al. 2014). }\end{array}$ & No evidence from NCOs. & $\begin{array}{l}\text { Suggests contingency } \\
\text { approach to SL } \\
\text { required in COs } \\
\text { while more universal } \\
\text { application suggested } \\
\text { in NCOs. }\end{array}$ \\
\hline Mediators & $\begin{array}{l}\text { Social integration (Avolio et } \\
\text { al. 1996); citizenship (Pearce } \\
\text { and Sims, 2002); networking } \\
\text { (Pearce and Sims, 2002); } \\
\text { increased awareness of team } \\
\text { member capabilities (Ocker et } \\
\text { al. 2011); information sharing } \\
\text { (Hoch, 2013); knowledge } \\
\text { sharing (Huang, 2013). }\end{array}$ & $\begin{array}{l}\text { Enhanced peer collaboration (James et al. } \\
\text { 2007); participative \& innovative culture } \\
\text { (Buchanan et al. 2007); enhanced dynamic } \\
\text { capabilities of the org. (Reid \& } \\
\text { Karambayya, 2009); enhanced mental } \\
\text { health of team members (Haward et al., } \\
\text { 2003). }\end{array}$ & $\begin{array}{l}\text { Some similarity in } \\
\text { relation to mediators } \\
\text { in COs and NCOs at } \\
\text { team level. } \\
\text { Additional mediators } \\
\text { identified at } \\
\text { individual and } \\
\text { organizational levels } \\
\text { in NCOs. }\end{array}$ \\
\hline Outcomes & $\begin{array}{l}\text { Team performance (Avolio et } \\
\text { al. 1996; Pearce and Ensley } \\
\text { 2001; Carson et al. 2007). } \\
\text { Team effectiveness (Acar, } \\
\text { 2010) arising from enhanced } \\
\text { team creativity (Lee et al. } \\
\text { 2015); higher intragroup trust } \\
\text { and team cohesion (Bergman } \\
\text { et al. 2012), (Mathieu et al. } \\
\text { 2015); team learning (Huang, } \\
\text { 2013). }\end{array}$ & $\begin{array}{l}\text { Improved performance (Hiller et al. 2006); } \\
\text { increased employee commitment (Hulpia et } \\
\text { al. 2010), increased job satisfaction (Wood } \\
\text { and Fields 2007); employee involvement } \\
\text { and greater empowerment (Klakovich, } \\
\text { 1996; Upenieks, 2000); flow and creativity } \\
\text { (Hooker and Csikszentmihalyi 2003). }\end{array}$ & $\begin{array}{l}\text { Predominant focus in } \\
\text { COs is team } \\
\text { performance. Some } \\
\text { evidence of this in } \\
\text { NCOs though not to } \\
\text { the same extent. }\end{array}$ \\
\hline
\end{tabular}

Table 5 - Comparing Shared Leadership in Commercial and Non-Commercial Settings

As outlined in Table 5, shared leadership research in commercial settings has been predominantly focused on teams and team performance, with little research conducted at the organizational level of analysis. Contrastingly, in non-commercial sectors such as healthcare and education, research on shared leadership has encompassed a broader range of organizational activities, including organizational change, organization design and organizational learning. This suggests a more organization-wide commitment to shared approaches to leadership in NCOs, than is the case in the commercial domain. This may 
reflect a view in commercial settings that shared leadership can enhance team leadership, but perhaps is not seen as contributing to organizational leadership in a wider sense.

To explore this, it is useful to consider how shared leadership is conceptualised in both contexts. Comparing empirical literature from the education sector with the commercial context reviewed earlier, conceptual differences are immediately apparent as the dominant term used by researchers is 'distributed leadership', with some contributors defining this as the extent to which leadership functions are distributed among formal leadership positions in the leadership team (Hulpia et al. 2010). While others extend this to suggest that leadership can be enacted by the entire educational community (Copland 2003), the former view implies a more orchestrated approach than is characteristic of how shared leadership is viewed in commercial contexts.

Spillane (2006) explains that distributed leadership in an educational context refers to leadership practice that is stretched across leaders, followers and their situations. Thus, from this perspective, distributed leadership encompasses both the established (vertical) leadership structures in school hierarchies, as well as other organizational members that interact with those structures, depending on the situation. Similarly, in the healthcare sector, while researchers refer to both 'shared leadership' (Jackson 2000; Willcocks and Wibberley 2015) and 'distributed leadership' (Buchanan et al. 2007) the majority refer to leadership as being 'distributed across levels, including informal and formal roles, in a collective organizationwide perspective' (Barrett et al. 2007: 265). Contrastingly, in commercial organizations, research has tended to focus on evidence of individuals informally sharing in the leadership of their team, and less on how this interplays with formal (vertical) leadership structures. Thus, although the management literature has taken a blended approach to shared leadership 
research across commercial and non-commercial settings, there are clearly differences in how shared leadership has been conceptualised by researchers in these different contexts.

Importantly however, studies from both commercial and non-commercial contexts reveal that shared leadership is accomplished through the interactions of multiple individuals, and that these interactions are key to the practice of shared leadership. While research in the commercial domain has yet to explore the interactions of individuals sharing leadership responsibilities, Spillane et al. (2004: 17) identify interdependency as the primary characteristic of interactions among school leaders, explaining that 'interdependency emerges when the enactment of a leadership task depends on the inter-play between two or more actors'. Spillane et al. (2004) further classify three types of interdependencies - reciprocal, pooled and sequential. Further empirical work is required to compare these findings to shared leadership interactions in commercial settings, thus it is difficult at this point to examine whether shared leadership may operate differently in these different domains. It is however anticipated that exploring shared leadership interactions in more dynamic commercial settings may be more complex than in educational settings, where researchers have adopted a taskcentred approach, enabled by a wide body of literature identifying pre-defined leadership practices which are linked with effective school leadership (Spillane et al. 2004).

Comparing antecedents of shared leadership, studies in religious and educational contexts broadly align with findings in commercial contexts, indicating that shared purpose and vision, teamwork and teambuilding processes, trust, empowering management approaches, team member openness, and representation of diverse constituencies are important facilitators of shared leadership in NCOs (Slantcheva-Durst 2014; Wood and Fields 2007). However, subtle differences noted in Table 5 in relation to team composition, suggest that the concept of a 
team may have a different meaning in the different domains. Within NCOs for instance, a key feature of team composition is the representation of diverse constituencies, such that individuals may belong to a variety of groups or networks, where they may simply be representing their unit. Such groups may not operate as a team as envisaged in the management literature (Bate and Robert 2002). Thus, in addition to differences in conceptualisations of shared leadership, the concept of an organizational group or team may have a different meaning in NCOs than in COs.

Furthermore, while studies in commercial settings have focused primarily on internal organizational conditions, of note in the education sector in particular is the importance of the external environment. Currie et al. (2009) for instance explored the impact of government policies and regulatory frameworks, as well as levels of social affluence on the emergence of distributed approaches to leadership in educational institutions in the UK, concluding that the implementation of shared leadership is most difficult in socially deprived areas. Spillane et al. (2004) also identify the sociocultural context of the situation as an important element of leadership practice. This level of analysis is lacking in the commercial domain, and while social factors may not be as significant in this milieu, research on influencing factors in the external environment could be useful to explore how forces at these levels might affect the enactment of shared leadership in such organizations. For instance, micro environments that are intensely competitive in nature might impede the development of shared leadership, as commercial pressures could generate more target-oriented managerial behaviours. This undermines empowerment according to Argyris (2001: 98), who questions the potential for real empowerment when 'managers just want to see better numbers'. 
In the healthcare sector, antecedents somewhat align with findings in commercial contexts, with employee commitment, staff autonomy, managerial guidance, collaborative decisionmaking, a culture of innovation, and a shared organizational vision identified as conditions facilitating the emergence of shared leadership (Currie and Lockett 2011; Jackson 2000). While most commentators recommend a bottom up approach to enacting leadership in healthcare organizations however (Buchanan et al. 2007), others advise that a hierarchy of expert authority is required for the smooth transfer of leadership between members at different levels (Klein et al. 2006). Evidence from this healthcare study (Klein et al. 2006: 28) notes the importance of 'bureaucratic structures combined with flexibility-enhancing processes', where senior members have expertise that more junior member's lack. Again, the interplay between different levels in the organizational hierarchy has not been explored in commercial settings, where researchers have tended to focus on leadership acts among peers in the context of their team.

While many of the antecedents identified in commercial and non-commercial contexts are similar (e.g. shared purpose, interdependency), the associated challenges for implementation may vary in the different domains. For instance, there are considerable challenges for COs associated with blending individualism and teamwork, when it comes to performance management and rewards. Despite the growing use of team goals (Suutari and Tahvanainen 2002), appraisal and reward tools are still predominantly individual (Emery 2004). This contradiction may be more pronounced in the commercial sector where expectations of individual financial rewards or career progression are typically higher. Such management practices which have an individualistic focus could undermine the collective orientation necessary for shared leadership to emerge. In contrast, individualistic reward mechanisms are uncommon in NCOs, where managers typically have little authority to determine the pay of 
their individual employees, reflecting a more centralised approach to personnel management in such organizations (Bozeman and Bretschneider 1994; Rainey and Bozeman 2000; Rainey et al. 1995). However, studies to date have not explored the extent to which individualised performance appraisals or rewards might be a barrier to the implementation of shared leadership.

In terms of outcomes of shared leadership, while there has been an emphasis on analysing performance outcomes in commercial contexts, there has been less focus on this in noncommercial settings. This is perhaps not surprising, given the difficulty in measuring performance related outcomes in NCOs, where improvements are judged not by market mechanisms but by the addition of public value (Moore 1995). While evidence on performance outcomes is to some extent lacking however, other outcomes have been explored. For instance, Hooker and Csikszentmihalyi (2003) found a reciprocal relationship between flow, creativity and shared leadership, which in turn, augment the effectiveness of groups. Wood and Fields (2007) found that a shared leadership approach in Christian church organizations was positively related to job satisfaction. Additionally, Hulpia et al. (2010) conclude that the presence of a shared approach to leadership in schools plays a significant positive role in predicting teachers' organizational commitment.

Clearly, progress has been made in both commercial and non-commercial domains, though researchers have taken different perspectives reflecting the differing priorities of each sector. It would appear that further progress has been made in the non-commercial sector, particularly in relation to understanding the underlying dynamics of the shared leadership process itself and this is a critical gap in relation to commercial contexts. More importantly, this comparison has identified significant differences in the conceptualisation of shared 
leadership in commercial and non-commercial settings, which suggests the need for contextspecific empirical research in this field. Developing this point, the following section provides some recommendations for future research in the commercial domain.

\section{Directions for Future Research}

The framework presented in Fig. 1 synthesizes findings on shared leadership research in COs so far. While progress has been made, there is significant scope for further research to develop an understanding of aspects of shared leadership that have received little attention to date (Conger and Pearce 2003). It has already been highlighted that further research is required to identify the effects of other variables on both the emergence of shared leadership and its impact on team performance. Variables which could be studied in this regard include the tenure, ability and motivation of team members, as well as other factors relating to team composition, including for example team life-cycle stages and cultural diversity. Further research could also investigate other outcomes of shared leadership in commercial settings, such as the impact of shared leadership on individuals (e.g. job satisfaction, commitment), teams (e.g. collective team efficacy, team potency), or at an organizational level (e.g. innovation). According to Drath et al. (2008), in contexts that are increasingly collaborative, the presence of leadership is marked by the accomplishment of outcomes such as direction, alignment and commitment. Adopting this ontology of leadership, further research exploring 'how people who share work in collectives produce direction, alignment and commitment' would be valuable (Drath et al. 2008: 636).

More important however is the need for future studies to explore the underlying dynamics of the shared leadership process itself, to explain how shared leadership actually unfolds in the interactions between individuals in commercial settings. For instance, such research could 
investigate whether the reciprocal, pooled and sequential patterns of interactions reported in educational settings (Spillane et al. 2004) are evident in the commercial domain. Shared leadership implies a role for multiple group members in the leadership of their group (Seibert et al. 2003), but research to date has not explained how this happens in a commercial context. This review has highlighted a gap in existing research in relation to the actual processes or mechanisms underlying shared leadership in commercial settings. To address this gap, future research investigating the interactions of team members sharing leadership responsibilities is an important avenue of investigation. For instance, longitudinal case studies exploring shared leadership interactions through qualitative methods in a variety of organizational contexts, could provide important insights into the shared leadership process itself.

Additionally, this paper proposes that future research should seek to build on more appropriate theoretical foundations which accommodate the relational and interactive nature of shared leadership. This review has shown that the dominant approach of aggregating leadership behaviours (such as directive and transactional) is rooted in vertical leadership perspectives which are inadequate for this purpose. Likewise, social network approaches, while accommodating a more relational perspective, also fall short of explaining the underlying processes leading up to the presence of shared leadership. Thus, improved theorization is needed to provide frameworks that enable studies of shared leadership to focus on the practices of people in interaction (Crevani et al. 2010).

Such research could advance our understanding of how 'interactants' share the leadership space (Chreim 2015: 3); which leadership responsibilities are suitable for sharing; and how individuals make choices regarding whether or not to share in the leadership process. Research exploring the interactions at the heart of shared leadership could also reveal how the 
nature of social relationships in a group (e.g. trust, perceived support, affective commitment) impact shared leadership practices; what costs (e.g. time, expertise) and rewards (e.g. satisfaction, social approval) are associated with contributing to shared leadership; what are the outcomes (e.g. commitment, goal accomplishment) of shared leadership interactions; what forms of influence are effective in these situations; and whether acts of shared leadership are reciprocated by others over time. Reflecting the temporal nature of the concept and the dynamic nature of commercial environments, such studies should be longitudinal, to uncover how shared leadership processes evolve over time (Hoch and Kozlowski 2014).

For illustrative purposes, Fig. 2 below provides a tentative model to summarise this discussion and to frame a proposed research agenda for future studies in the field.

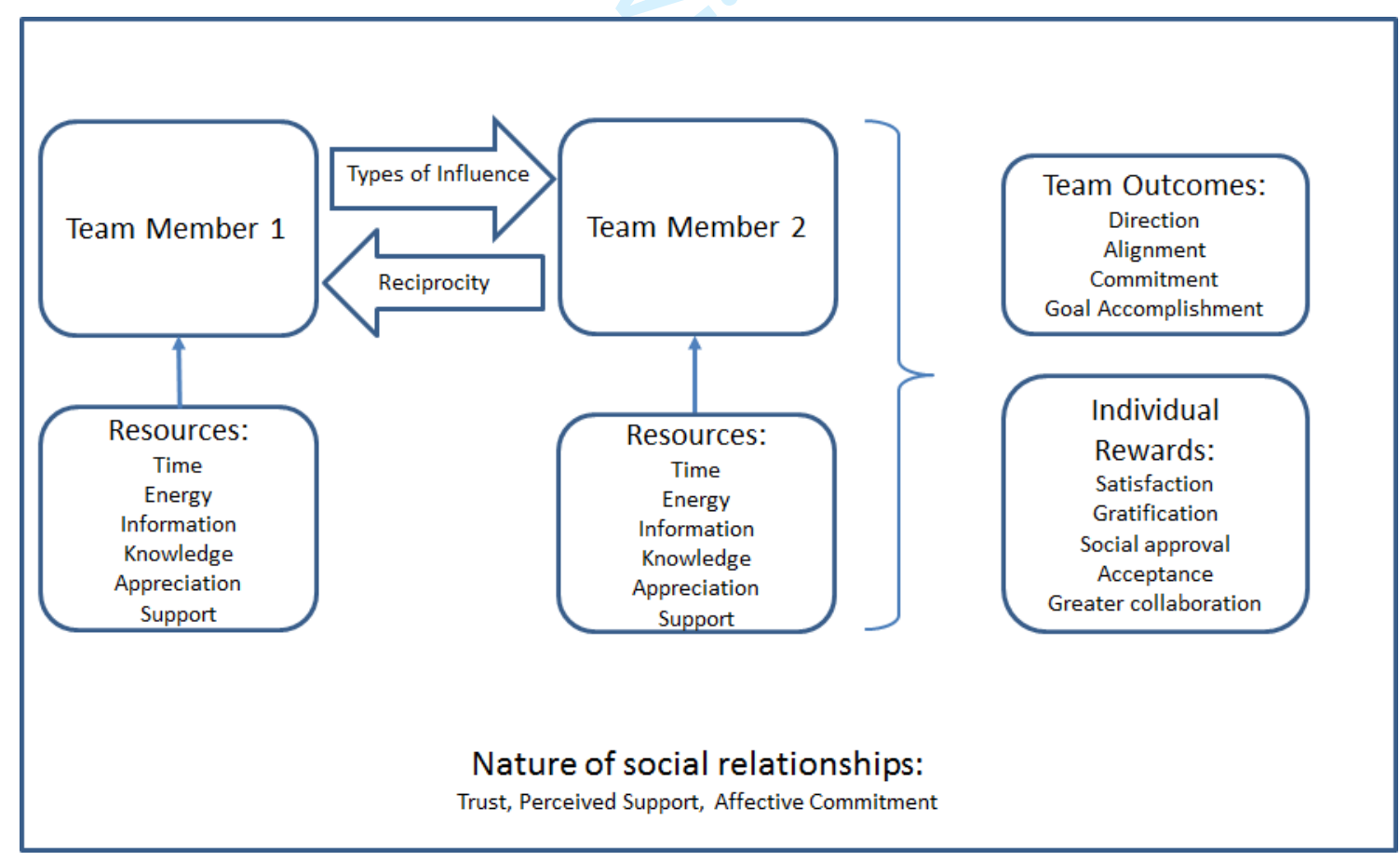

Fig. 2: Proposing a Future Research Agenda. 
This review has extended the discussion on shared leadership in the commercial sphere. Future research could extend this by examining shared leadership practices in diverse commercial contexts, examining more specifically the challenges for example in service organizations compared to manufacturing firms. Certainly, given the reliance on more simulated contexts in many of the studies reviewed here, further empirical work in a wider range of real-world organizational settings would be beneficial.

\section{Conclusion}

Reviewing the empirical literature has enabled us to develop an understanding of how shared leadership has been conceptualised, theorised, and researched to date, and the impact it has had in commercial organizations. Comparisons with other settings indicate that there are important differences in the conceptualisation of shared leadership across commercial and non-commercial sectors, confirming the need for context-specific research in this field. This review has contributed to theory and practice, by presenting a framework of current findings specific to the commercial sector, identifying antecedent conditions and performance outcomes, while revealing critical gaps in existing shared leadership research. Moreover, this review has exposed a number of inconsistencies in how shared leadership is defined and inadequacies in theoretical frameworks and measurement approaches employed thus far. Consequently, this paper calls for improved theorization about shared leadership, recommending the pursuit of research frameworks which focus on the practices of people in interaction. Finally, to advance the development of theory in this field, this paper calls for longitudinal, qualitative investigations of shared leadership practices in a variety of organizational contexts, to develop our understanding of the interactions at the heart of this alternative form of leadership. 


\section{References}

Acar, F. P. (2010). Analyzing the effects of diversity perceptions and shared leadership on emotional conflict: a dynamic approach. The International Journal of Human Resource Management, 21, No. 10, pp. 1733-1753.

Allison, G. (1979). Public and private management: are they fundamentally alike in all unimportant respects? In Shafritz, J. and Hyde, A. (Eds), Classics of Public Administration, Belmont: Wadsworth.

Andersen, J.A. (2010). Public versus Private Managers: How Public and Private Managers Differ in Leadership Behaviour. Public Administration Review, 70, No. 1, pp. 131-141.

Andrews, R., Boyne, G.A., and Walker, R.M. (2011). Publicness and organizational performance. Journal of Public Administration Research and Theory, 21, No. 3, pp. 301-319.

Argyris, C. (2001). Empowerment: The Emperor's New Clothes. In J. Henry (Ed), Creative Management, pp.98-105, UK: Sage Publications.

Aulich, C. (2011). Its not ownership that matters: its publicness. Policy Studies, 32, No. 3, pp. 199-213.

Avolio, B., Jung, D. Murry, W. and Sivasubramaniam N. (1996). Building highly developed teams: Focusing on shared leadership process, efficacy, trust, and performance. In M.M. Beyerlein, D.A. Johnson, and S.T. Beyerlein (Eds), Advances in interdisciplinary studies of work teams pp. 173-209. Greenwich, CT: JAI Press.

Avolio, B., Walumbwa, F. and Weber, T. (2009). Leadership: Current theories, research, and future directions. Annual Review of Psychology, 60, No. 1, pp. 421-449.

Barrett, L.L., Plotnikoff, R.C. and Raine, K. (2007). Organizational leadership and its relationship to regional health authority actions to promote health. Journal of Health Organization and Management. 21, No. 3, pp. 259-282.

Bate, P. and Robert, G. (2002). Knowledge management and communities of practice in the private sector: lessons for modernizing the Natinal Health Service in England and Wales. Public Administration, 80, pp. 643-663.

Bello, D., Leung, K., Radebaugh, L, Tung, R.L. and van Witteloostuijn, A. (2009). From the Editors: Student samples in international business research. Journal of International Business Studies, 40, pp. 361-364.

Bergman, J. Z., Rentsch, J. R., Small, E. E., Davenport, S.W., and Bergman, S. M. (2012). The shared leadership process in decision-making teams. The Journal of Social Psychology, 152, No. 1, pp. 17-42.

Berman, E., West, J. and Cava, A. (1994). Ethics management in municipal governments and large firms: exploring similarities and differences. Administration and Society, 26, pp. 185203. 
Boies, K., Lvina, E., and Martens, M.L. (2010). Shared leadership and team performance in a business strategy simulation. Journal of Personnel Psychology, 9, pp. 195-202.

Bolden, R. (2004). What is Leadership? Leadership South West Research Report 1, UK: University of Exeter Centre for Leadership Studies.

Bolden, R. (2011). Distributed Leadership in Organizations: A Review of Theory and Research. International Journal of Management Reviews, 13, pp. 251-269.

Bourantas, D. and Papalexandris, N. (1993). Differences in Leadership Behaviour and Influence Between Public and Private Organizations in Greece. The International Journal of Human Resource Management, 4, No. 4, pp. 859-871.

Boyne, G.A. (2002). Public and Private Management: What's the Difference? Journal of Management Studies, 39, No. 1, pp. 97-122.

Boyne, G. A., Jenkins, G. and Poole, M. (1999). Human resource management in the public and private sectors: an empirical comparison. Public Administration, 77, pp. 407-420.

Bozeman, B. (1987). All Organizations Are Public. London: Jossey-Bass.

Bozeman, B. (2007). Public values and public interest: counterbalancing economic individualism. Washington, DC: Georgetown University Press.

Bozeman, B. and Bretschneider, S. (1994). The 'Publicness Puzzle' in Organization Theory: A Test of Alternative Explanations of Differences Between Public and Private Organizations, Journal of Public Administration Research and Theory, 4, No. 2, pp. 197-223.

Bryman, A, and Stephens, M. (1996). The importance of context: Qualitative research and the study of leadership. Leadership Quarterly, 7, No. 3, pp. 353-371.

Buchanan, D.A., Addicott, R., Fitzgerald, L., Ferlie, E. and Baeza, J.I. (2007). Nobody in charge: distributed change agency in healthcare. Human Relations, 60, pp. 1065-1090.

Burke, C.S., Fiore, S.M, and Salas, E. (2003). The Role of Shared Cognition in Enabling Shared Leadership and Team Adaptability, in Pearce, C.L., and Conger, J.A. (Eds), Shared Leadership Reframing the Hows and Whys of Leadership, pp.103-122, USA: Sage.

Campbell, J.P., McCloy, R.A., Oppler, S.H., and Sager, C.E. (1993). A theory of performance. In Schmitt N. \& Borman W. (Eds.), Personnel selection in organizations, pp. 35-70. San Francisco, CA: Jossey-Bass.

Carson, J.B., Tesluk, P.E., and Marrone, J.A. (2007). Shared leadership in teams: An investigation of antecedent conditions and performance. Academy of Management Journal, 50, No. 5, pp 1217-1234.

Carte, T. A., Chidambaram, L., and Becker, A. (2006). Emergent leadership in self-managed virtual teams: A longitudinal study of concentrated and shared leadership behaviors. Group Decision and Negotiation, 15, No. 4, pp. 323-343. 
Cater, J.J. III and Justis, R.T. (2010). The development and implementation of shared leadership in multi-generational family firms. Management Research Review, 33, No. 6, pp. 563-585.

Chreim, S. (2015). The (non)distribution of leadership roles: Considering leadership practices and configurations. Human Relations, 68, No. 4, pp. 517-543.

Christensen, T., and Laegreid, P. (2017). Transcending New Public Management: The Transformation of New Public Sector Reforms, Denmark: Routledge.

Chrobot-Mason, D., Gerbasi, A. and Cullen-Lester, K.L. (2016) Predicting leadership relationships: The importance of collective identity. The Leadership Quarterly, 27, pp. 298311.

Clarke, N. (2012). Shared leadership in projects: a matter of substance over style, Team Performance Management, 18, No. 3/4, pp. 196-209.

Clarke, N. (2018). Relational leadership: Theory, Practice and Development. London: Routledge.

Conger, J.A., and Pearce, C.L. (2003). A landscape of opportunities: Future research in shared leadership. In Pearce, C.L., and Conger, J.A. (Eds), Shared Leadership Reframing the Hows and Whys of Leadership, pp.285-303, USA: Sage.

Cook, K.S. and Rice, E. (2003). Social Exchange Theory. In Delamater, J. (Ed.) Handbook of Social Psychology, New York: Kluwer Academic/Plenum Publishers.

Cope, J., Kempster, S., and Parry, K. (2011). Exploring Distributed Leadership in the Small Business Context. International Journal of Management Reviews, 13, pp. 270-285.

Copland, M.A. (2003). Leadership of inquiry: Building and sustaining capacity for school improvement. Educational evaluation and policy analysis, 25, No. 4, pp.375-395.

Crevani, L., Lindgren, M. and Packendorff, J. (2007). Shared Leadership: A Postheroic Perspective on Leadership as a Collective Construction. International Journal of Leadership Studies, 3, No. 1, pp. 40-67.

Crevani, L., Lindgren, M. \& Packendorff, J. (2010). Leadership, not leaders: On the study of leadership as practices and interactions. Scandinavian Journal of Management, 26, 1, 77-86.

Currie, G., Lockett, A. and Suhomlinova, O. (2009). The institutionalization of distributed leadership: A 'Catch-22' in English public services, Human Relations, 62, No. 11, pp. 17351761.

Currie, G. and Lockett, A. (2011). Distributing Leadership in Health and Social Care: Concertive, Conjoint or Collective? International Journal of Management Reviews, 13, pp. 286-300. 
Daspit, J., Tillman, C.J., Boyd, N.G. and Mckee, V. (2013). Cross-functional team effectiveness - an examination of internal team environment, shared leadership and cohesion influences. Team Performance Management, 19, No. 1/2, pp. 34-56.

D’Innocenzo, L., Mathieu J.E., and Kukengerger, M.R. (2014). 'A Meta-Analysis of Different Forms of Shared Leadership-Team Performance Relations', Journal of Management, Published online 10 March, 2014.

Drath, W.H., McCauley, C.D., Palus, C.J., Van Velsor, E., O'Connor, P.M.G., McGuire, J.B. (2008). Direction, alignment, commitment: Toward a more integrative ontology of leadership. The Leadership Quarterly, 19, pp. 635-653.

Drescher, M.A., Korsgaard, M.A., Welpe, I.M., and Picot, A. (2014). The Dynamics of Shared Leadership: Building Trust and Enhancing Performance. Journal of Applied Psychology, 99, No. 5, pp. 771-783.

Eckel, P.D. and Kezar, A.J. (2003). Taking the reins: Institutional transformation in higher education, UK: Greenwood Publishing Group.

Emery Y. (2004). Rewarding civil service performance through team bonuses: findings, analysis and recommendations. International Review of Administrative Sciences, 70, No. 1, pp. $157-168$.

Ensley, M.D., Hmieleski, K.M., and Pearce, C.L. (2006). The importance of vertical and shared leadership within new venture top management teams: Implications for the performance of start-ups. The Leadership Quarterly, 17, No. 3, pp 217-231.

Erez, A., Lepine, J.A., and Elms, H. (2002). Effects of rotated leadership and peer evaluation on the functioning and effectiveness of self-managed teams: a quasi-experiment. Personnel Psychology, 55, No. 4, pp. 929-948.

Erkutlu, H. (2012). The impact of organizational culture on the relationship between shared leadership and team proactivity. Team Performance Management, 18, No.1/2, pp. 102-119.

Farnham, D. and Horton, S. (1996). Managing public and private organizations. In Farnham, D. and Horton, S. (Eds). Managing the New Public Services, London: Macmillan.

Fausing, M.S., Jeppesen, H.J. and Jonsson, T.S. (2013). Moderators of shared leadership: work function and team autonomy. Team Performance Management, 19, No. 5/6, pp. 244262.

Fausing, M.S., Joensson, T.S., Lewandowski, J. and Bligh, M. (2015). Antecedents of shared leadership: empowering leadership and interdependence. Leadership \& Organization Development Journal, 36, No. 3, pp. 271-291.

Fitzsimons, D., Turnbull J.K. and Denyer, D. (2011). Alternative Approaches for Studying Shared and Distributed Leadership. International Journal of Management Reviews, 13, pp. 313-338. 
Fottler, M. (1981). Is management really generic? Academy of Management Review, 6, pp. 112.

Fowler, A. (1990). What is different about managing non-governmental organizations (NGOs) involved in Third World Development, NGO Management, No. 12, International Council of Voluntary Agencies, Geneva, January-March.

Freeman, R.E. (1984). Strategic Management: A Stakeholder Approach. Boston, MA: Pitman Press.

Friedrich, T. L., Vessey, W. B., Schulke, M. J., Ruark, G. A., and Mumford, M. D. (2011). A framework for understanding collective leadership: The selective utilization of leader and team expertise within networks. The Leadership Quarterly, 20, pp. 933-958.

Goulet, L.R. and Frank, M.L. (2002). Organizational Commitment across Three Sectors: Public, Non-profit, and For-profit. Public Personnel Management, 31, No. 2, pp. 201-210.

Greenfield, D., Braithwaite, J., Pawsey, M., Johnson, B. and Robinson, M. (2009). Distributed leadership to mobilise capacity for accreditation research. Journal of Health Organization and Management, 23, No. 2, pp.255-267.

Grint, K. (2000). The Art of Leadership. Oxford, UK: Oxford University Press.

Gronn, P. (2002). Distributed Leadership as a Unit of Analysis. The Leadership Quarterly, 13, pp.423-451.

Gupta, V.K., Huang, R., and Yayla, A. (2011). Social capital, collective transformational leadership, and performance: A resource-based view of self-managed teams. Journal of Managerial Issues, 23, pp. 31-45.

Guzzo, R. A., Salas, E., \& Associates. (1995). Team effectiveness and decision-making in organizations. San Francisco: Jossey-Bass.

Hart, C. (1998). Doing a literature review: Releasing the social science research imagination. Thousand Oaks, California: Sage Publications.

Hackman, J. R. (1987). The design of work teams. In J. Lorsch (Ed). Handbook of Organizational Behavior, pp. 315-342. Englewood Cliffs, NJ: Prentice-Hall.

Hansen, J.R., and Villadsen, A.R. (2010). Comparing Public and Privat Managers' Leadership Styles: Understanding the Role of Job Context. International Public Management Journal, 13, No. 3, pp. 247-274.

Hartley, J. and Benington, J. (2006). Copy and paste, or graft and transplant? Knowledge sharing through inter-organizational networks. Public Money and Management, 26, No. 2, pp. 101-108.

Haward, R., Amir, Z., Borrill, C., Dawson, J., Scully, J., West, M. and Sainsbury, R. (2003). Breast cancer teams: the impact of constitution, new cancer workload, and methods of operation on their effectiveness. British Journal of Cancer, 89, No. 1, pp.15-22. 
Higgs, M.J. (2003). How can we make sense of leadership in the $21^{\text {st }}$ century? Leadership \& Organization Development Journal, 24, No. 5, pp 273-284.

Hildebrand, D., Droge, H., Marsick, V. (2012). Shared Leadership and its Role in Team Learning. Paper presented by GRACO Research Group, Universitat Ramon Llull, Barcelona.

Hill, G. W. (1982). Group versus individual performance: Are $\mathrm{N}+1$ heads better than one? Psychological Bulletin, 91, No. 3, pp. 517-539.

Hiller, N. J., Day, D.V. and Vance, R.J. (2006). Collective enactment of leadership roles and team effectiveness: A field study. The Leadership Quarterly, 17, No. 4, pp: 387-397.

Hoch, J.E. (2013). Shared Leadership and Innovation: The Role of Vertical Leadership and Employee Integrity. Journal of Business Psychology, 28, pp. 159-174.

Hoch, J.E. (2014). Shared leadership, diversity, and information sharing in teams. Journal of Managerial Psychology, 29 Iss 5 pp. 541 - 564.

Hoch, J.E. and Dulebohn, J.H. (2013). Shared leadership in enterprise resource planning and human resource management system implementation, Human Resource Management Review, 23, pp. 114-125.

Hoch, J.E. and Dulebohn, J.H. (2017). Team personality composition, emergent leadership and shared leadership in virtual teams: A theoretical framework. Human Resource Management Review, http://dx.doi.org/10.1016/j.hrmr.2016.12.012.

Hoch, J.E. and Kozlowski, S.W. (2014). Leading Virtual Teams: Hierarchical Leadership, Structural Supports, and Shared Team Leadership. Journal of Applied Psychology, 99, No. 3, pp. 390-403.

Hoch, J.E., Pearce, C.L. and Welzel, L. (2010). Is the most effective team leadership shared? The impact of shared leadership, age diversity and coordination on team performance. Journal of Personnel Psychology, 9, No. 3, pp 105-116.

Hollander, E.P., and Offermann, L.R. (1990). Power and leadership in organizations: Relationships in transition. American Psychologist, 45, No. 2, p. 179.

Hood, C. (1991). A public management for all seasons? Public Administration, 69, pp. 3-19.

Hooker, C. and Csikszentmihalyi, M. (2003). Flow, Creativity, and Shared Leadership: Rethinking the Motivation and Structuring of Knowledge Work. In Pearce, C.L., and Conger, J.A. (Eds), Shared Leadership Reframing the Hows and Whys of Leadership, pp. 215-229, USA: Sage.

Huang, C. (2013). Shared Leadership and Team Learning: Roles of Knowledge Sharing and Team Characteristics. The Journal of International Management Studies, 8, No. 1, pp. 124133. 
Hulpia, H., Devos, G. and Van Keer, H. (2010). The Influence of Distributed Leadership on Teachers' Organizational Commitment: A Multilevel Approach, The Journal of Educational Research, 103, pp. 40-52.

Ishikawa, J. (2012). Transformational leadership and gatekeeping leadership: The roles of norm for maintaining consensus and shared leadership in team performance. Asia Pacific Journal of Management, 29, pp. 265-283.

Jackson, S. (2000). A qualitative evaluation of shared leadership barriers, drivers and recommendations. Journal of Management in Medicine. 14, No. 3/4, pp 166-178.

Jain, A.K. and Jeppesen, H.J. (2014). Conceptualizing and implementing the distributed leadership practices in Indian organizations. Journal of Management Development, 33, No. 3, pp. 258-278.

James, K.T., Mann, J. and Creasy, J. (2007). Leaders as Lead Learners A Case Example of Facilitating Collaborative Leadership Learning for School Leaders. Management Learning, 38, No. 1, pp.79-94.

Klakovich, M.D. (1996). Registered nurse empowerment: Model testing and implications for nurse administrators. Journal of Nursing Administration, 26, No. 5, pp. 29-35.

Klein, K.J., Ziegert, J.C., Knight, A.P. and Xiao, Y., (2006). Dynamic delegation: Shared, hierarchical, and deindividualized leadership in extreme action teams. Administrative Science Quarterly, 51, No. 4, pp.590-621.

Lee, D.S., Lee, K.C., Seo, Y.W., and Choi, D.Y. (2015). An analysis of shared leadership, diversity and team creativity in an e-learning environment. Computers in Human Behavior, 42, pp. 47-56.

Leithwood, K., Day, C., Sammons, P., Harris, A. \& Hopkins, D. (2006). Successful School Leadership: What It Is and How It Influences Pupil Learning, Nottingham: DfES Publications.

Lindkvist, L. (2004). Knowledge communities and knowledge collectivities: a typology of knowledge work in groups. Journal of Management Studies, 42, No. 6, pp. 1189-1210.

Liu, S., Hu, J., Li, Y., Wang, Z., and Lin, X. (2014). Examining the cross-level relationship between shared leadership and learning in teams: Evidence from China. The Leadership Quarterly, 25, No. 2, pp. 282-295.

Locke, E. (2003). Leadership: 'Starting at the top'. In Pearce, C.L., and Conger, J.A. (Eds), Shared Leadership Reframing the Hows and Whys of Leadership, pp. 271-284, Sage, USA.

Luscher, L. and Lewis, M.W. (2008). Organizational change and managerial sensemaking: working through paradox. Academy of Management Journal, 51, pp. 221-240.

Maier, N. R. (1967). Assets and liabilities in group problem solving: The need for an integrative function. Psychological Review, 74, No. 4, pp. 239-249. 
Mathieu, J.E., Kukenberger, M.R., D’Innocenzo, L. and Reilly, G. (2015). Modeling Reciprocal Team Cohesion-Performance Relationships, as Impacted by Shared Leadership and Members' Competence, Journal of Applied Psychology, 100, No. 3, pp. 713-734.

Mehra, A., Smith, B.R., Dixon, A.L., and Robertson, B. (2006). Distributed leadership in teams: The network of leadership perceptions and team performance. Leadership Quarterly, 17, pp. 232-245.

Meier, K.J., and O'Toole, L.L. (2006). Bureaucracy in a democratic state: A governance perspective. Baltimore, MD: Johns Hopkins University Press.

Mendez, M.J., and Busenbark, J.R. (2015). Shared leadership and gender: all members are equal...but some more than others. Leadership and Organization Development Journal, 36, No. 1, pp. 17-34.

Metcalfe, B. A. (1989). What motivates managers: an investigation by gender and sector of employment. Public Administration 67, No. 1, pp. 95-108.

Moore, M. (1995). Creating Public Value: Strategic Management in Government. Cambridge, MA: Harvard University Press.

Moulton, S. Wise, C. (2010). Shifting Boundaries between the Public and Private Sectors: Implications from the Economic Crisis. Public Administration Review, 70, No. 3, pp. 349360 .

Muethel, M., Gehrlein, S., and Hoegl, M. (2012). Socio-demographic factors and shared leadership behaviors in dispersed teams: implications for Human Resource Management. Human Resource Management, 51, No. 4, pp. 525-548.

Mulgan, R. (2000). Comparing Accountability in the Public and Private Sectors. Australian Journal of Public Administration, 59, No. 1, pp.87-97.

Nicolaides, V.C., LaPort, K.A., Chen, T.R., Tomassetti, A.J., Weis, E.J., Zaccaro, S.J. and Cortina, J.M. (2014). The shared leadership of teams: A meta-analysis of proximal, distal, and moderating relationships. The Leadership Quarterly, 25, pp.923-942.

Northouse, P.G. (2001). Leadership: Theory and Practice. Thousand Oaks, CA: Sage.

Nutt, P.C. (2000). Decision-making Success in Public, Private and Third Sector Organizations: Finding Sector Dependent Best Practice. Journal of Management Studies, 31, No. 1, pp. 77-108.

Nutt, P.C. and Backoff, R.W. (1993). Organizational publicness and its implications for strategic management. Journal of Public Administration Theory, 3, No. 3, pp. 209-231.

Nutt, P.C. and Backoff, R.W. (1995). Strategy for public and third sector organizations. Journal of Public Administration Research and Theory, 5, No. 2, pp. 189-211. 
Ocker, R.J., Huang, H., Benbunan-Fich, R., and Hiltz, S.R. (2011). Leadership Dynamics in Partially Distributed Teams: an Exploratory Study of the Effects of Configuration and Distance. Group Decision and Negotiation, 20, No. 3, pp. 273-293

O'Toole, J., Galbraith, J. and Lawler, E.E. (2002). When two (or more) heads are better than one: The promise and pitfalls of shared leadership. California Management Review, 44, No. 4, pp. $65-83$.

Oxford English Dictionary. (2017). [online] Available at:

https://en.oxforddictionaries.com/definition/aggregation [Accessed 20 Feb. 2017].

Park, J.G. and Kwon, B. (2013). Literature Review on Shared Leadership in Teams. Journal of Leadership, Accountability and Ethics, 10, No. 3, pp. 28-36.

Patton, D. and Higgs, M. (2013). The Role of Shared Leadership in the Strategic Decision Making Processes of New Technology Based Firms. International Journal of Innovation Management, 17, No. 4, pp.1-24.

Pearce, C.L. and Ensley, M.D. (2001). Shared cognition in top management teams: implications for new venture performance. Journal of Organizational Behavior, 22, pp. 146160.

Pearce, C.L. and Herbik, P.A. (2004). Citizenship Behavior at the Team Level of Analysis: The Effects of Team Leadership, Team Commitment, Perceived Team Support, and Team Size. The Journal of Social Psychology, 144, No. 3, pp. 293-310.

Pearce, C.L., and Manz, C.C. (2005). The importance of self- and shared leadership in knowledge work. Organizational Dynamics, 34, No. 2, pp. 130-140.

Pearce, C.L., Conger, J.A. and Locke, E.A. (2007). Theoretical and Practitioner Letters: Shared Leadership Theory. The Leadership Quarterly, 18, pp. 281-288.

Pearce, C.L. Manz, C.C. and Sims, H.R. (2008). The roles of vertical and shared leadership in the enactment of executive corruption: implications for research and practice. The Leadership Quarterly, 19, No. 3, pp. 353-359.

Pearce, C.L. and Manz, C.C. (2011). Leadership Centrality and Corporate Social IrResponsibility (CSIR): The Potential Ameliorating Effects of Self and Shared Leadership on CSIR. Journal of Business Ethics, No. 102, pp. 563-579.

Pearce, C.L., Manz, C.C. and Sims, H.R. Jr. (2009). Where Do We Go From Here?: Is Shared Leadership the Key to Team Success? Organizational Dynamics, 38, No. 3, pp 234-238.

Pearce, C.L. and Sims, H.P. (2000). Shared leadership: Toward a multi-level theory of leadership. Team Development, 7, pp. 115-139.

Pearce, C.L. and Sims, H.P. (2002). The relative influence of vertical vs. shared leadership on the longitudinal effectiveness of change management teams. Group Dynamics: Theory, Research, and Practice, 6, No. 2, pp172-197. 
Perry, J.L. and Rainey, H.G. (1988). The public-private distinction in organization theory: critique and research strategy. The Academy of Management Review, 13, No. 2, pp. 182-201.

Peterson, R.A. (2001). On the use of college students in social science research: Insights from a second-order meta-analysis. Journal of Consumer Research, 28, No. 3, pp. 450-461.

Peterson, R.A., and Merunka, D.R. (2014). Convenience samples of college students and research reproducibility, Journal of Business Research, 67, pp. 1035-1041.

Pettigrew, A. (2005). The character and significance of management research on the public services. Academy of Management Journal, 48, pp. 973-977.

Pettigrew, A. and Whipp, R. (1991). Managing change for competitive success. Oxford: Blackwell.

Petrovsky, N., James, O., and Boyne G.A. (2014). New Leaders' Managerial Background and the Performance of Public Organizations: The Theory of Publicness Fit. Journal of Public Administration Research and Theory, 25, pp. 217-236.

Rainey, H.G., Pandey, S. and Bozeman, B. (1995). Research Note: Public and Private Managers' Perceptions of Red Tape. Public Administration Review, 55, No. 6, pp. 567-574.

Rainey, H. G. and Bozeman, B. (2000). Comparing Public and Private Organizations: Empirical Research and the Power of the A Priori, Journal of Public Administration Research and Theory, 10, No. 2, pp. 447-469.

Ranson, S. and Stewart, J. (1994). Management for the Public Domain. London: St. Martin's Press.

Rashman, L., Withers, E. and Hartley, J. (2009). Organizational learning and knowledge in public service organizations: A systematic review of the literature. International Journal of Management Reviews, 11, No. 4, pp. 463-494.

Reid, W. and Karambayya, R. (2009). Impact of dual executive leadership dynamics in creative organizations. Human Relations, 62, No. 7, pp.1073-1112.

Rice, N. (2006). Opportunities lost, possibilities found: Shared leadership and inclusion in an urban high school. Journal of Disability Policy Studies, 17, No. 2, pp. 88-100.

Ring, P. and Perry, J. (1985). Strategic management in public and private contexts. Academy of Management Review, 10, No. 2, pp. 276-286.

Salas, E. and Fiore, S.M. (2004). Why team cognition? In E. Salas \& S.M. Fiore (Eds), Team cognition: Understanding the factors that drive process and performance, pp. 3-9. Washington, DC: American Psychological Association.

Seibert, S.E., Sparrowe, R.T. and Liden, R.C. (2003). A Group Exchange Structure Approach to Leadership in Groups. In Pearce, C.L. and Conger, J.A. (Eds), Shared Leadership Reframing the Hows and Whys of Leadership, pp. 173-214, USA: Sage. 
Serban, A. and Roberts, A. (2016). Exploring antecedents and outcomes of shared leadership in a creative context: A mixed-methods approach, The Leadership Quarterly, 27, pp. 181-199.

Shondrick, S.J., Dinh, J.E. and Lord, G. (2010). Developments in implicit leadership theory and cognitive science: applications to improving measurement and understanding alternatives to hierarchical leadership. Leadership Quarterly, 21, pp. 959-978.

Shortell, S., Morrison, E. and Friedman, B. (1990). Strategic Choices for America's Hospitals. San Francisco: Jossey-Bass.

Sivasubramaniam, N., Murry, W.D., Avolio, B.J., and Jung, D.I. (2002). A longitudinal model of the effects of team leadership and group potency on group performance. Group and Organization Management, 27, pp. 66-96.

Slantcheva-Durst, S. (2014). Shared Leadership as an Outcome of Team Processes: A Case Study. Community College Journal of Research and Practice, 38, No. 11, pp.1017-1029.

Small, E.E., and Rentsch, J.R (2010). Shared leadership in teams: A matter of distribution. Journal of Personnel Psychology, 9, No. 4, pp. 203-211.

Solansky, S.T. (2008). Leadership Style and Team Processes in Self-Managed Teams. Journal of Leadership and Organizational Studies, 14, No. 4, pp. 332-341.

Solomon, E. (1986). Private and public sector managers: an empirical investigation of job characteristics and organizational climate. Journal of Applied Psychology, 71, pp. 247-59.

Sparrowe, R.T., Liden, R.C. Wayne, S.J., and Kraimer, M.B. (2001). Social networks and the performance of individuals and groups. Academy of Management Journal, 44, pp. 316-325.

Spillane, J.P., Halverson, R. and Diamond, J.B. (2004). Towards a theory of leadership practice: a distributed perspective, Journal of Curriculum Studies, 36 No. 1, pp. 3-34.

Spillane, J.P. (2006). Distributed Leadership. San Francisco, CA: Jossey-Bass.

Stagnaro, C. and Piotrowski, C. (2013). Shared Leadership in IT Project Management: A Practice Survey. International Journal of Management and Information Systems, 17, No. 4, pp. 223-235.

Suutari V. and Tahvanainen M. (2002). The antecedents of performance management among Finnish expatriates. International Journal of Human Resource Management, 13, No. 1, pp. $55-75$.

Tesluk, P.E., Zaccaro, S.J., Marks, M. and Mathieu, J. (1997). Task and aggregation issues in the analysis and assessment of team performance. In M. Brannick and E Salas (Eds), Assessment and measurement of team performance: Theory, research and applications, pp. 197-224. Greenwich, CT: JAI Press.

Thorpe, R, Gold, J., and Lawler, J. (2011). Locating Distributed Leadership. International Journal of Management Reviews, 13, pp. 239-250. 
Torraco, R.J. (2005). Writing integrative literature reviews: Guidelines and examples. Human Resource Development Review, 4, No. 3, pp. 356-367.

Tranfield, D., Denyer, D., and Smart, P. (2003). Towards a Methodology for Developing Evidence-Informed Management Knowledge by Means of Systematic Review. British Journal of Management, 14, pp. 207-222.

Uhl-Bien, M. (2006). Relational leadership theory: exploring the social processes of leadership and organizing. Leadership Quarterly, 17, pp. 654-676.

Ulhoi, J.P. and Muller, S. (2014). Mapping the Landscape of Shared Leadership: A Review and Synthesis, International Journal of Leadership Studies, 8, No. 2, pp. 66-87.

Upenieks, V. (2000). The relationship of nursing practice models and job satisfaction outcomes. Journal of Nursing Administration, 30, No.6, pp. 330-335.

Vigoda-Gadot, E., and Meiri, S. (2008). New public management values and personorganization fit: A socio-psychological approach and empirical examination among public sector personnel. Public Administration, 86 No.1, pp. 111-131.

Waldersee, R. and Eagleson, G. (2002). Shared leadership in the implementation of reorientations. Leadership and Organization Development Journal, 24, No. 7, pp. 400-407.

Wang, D., Waldman, D.A., and Zhang, A. (2014). A Meta-Analysis of Shared Leadership and Team Effectiveness, Journal of Applied Psychology, 99, No. 2, pp. 181-198.

Wassenaar, C.L. and Pearce, C.L. (2012). The nature of shared leadership, in Day, D.V. and Antonakis, J. (Eds). The Nature of Leadership, $2^{\text {nd }}$ ed, pp. 363-389, Thousand Oaks, CA: Sage.

Wasserman, S, and Faust, K. (1994). Social network analysis: Methods and applications. New York, NY: Cambridge University Press.

Willcocks, S.G. and Wibberley, G. (2015). Exploring a shared leadership perspective for NHS doctors, Leadership in Health Services, 28, No. 4, pp. 345-355.

Wood, M.S. (2005). Determinants of shared leadership in management teams. International Journal of Leadership Studies, 1, No. 1, pp. 64-85.

Wood, M.S. and Fields, D. (2007). Exploring the impact of shared leadership on management team member job outcomes, Baltic Journal of Management, 2, No. 3, pp. 251-272.

Yukl, G.A. (1989). Managerial leadership: A review of theory and research. Journal of Management, 15, pp. 251-289.

Yukl, G.A. (2013). Leadership in Organizations ( $8^{\text {th }}$ Ed.) Englewood Cliffs, NJ: Pearson/Prentice Hall. 
Zhou, W., Vredenburgh, D. and Rogoff, E.G. (2015). Informational diversity and entrepreneurial team performance: moderating effect of shared leadership. International Entrepreneurship and Management Journal, 11, pp. 39-55.

Zhou, W. and Vredenburgh, D. (2017). Dispositional antecedents of shared leadership emergent states on entrepreneurial teams. In C. Ben-Hafaiedh and T.M Cooney (Eds), Research Handbook on Entrepreneurial Teams: Theory and Practice, p.164-184, UK: Edward Elgar Publishers Inc. 


\section{Appendix A - Definition of terms related to Shared Leadership}

\begin{tabular}{|c|c|c|}
\hline $\begin{array}{l}\text { Shared leadership } \\
\text { (SL) }\end{array}$ & $\begin{array}{l}\text { Conger \& } \\
\text { Pearce }(2003: \\
1) \text {. }\end{array}$ & $\begin{array}{l}\text { SL is 'a dynamic, interactive influence process among } \\
\text { individuals of a group for which the objective is to lead } \\
\text { one another to the achievement of group or organizational } \\
\text { goals or both'. }\end{array}$ \\
\hline Distributed (DL) & Gronn (2002) & $\begin{array}{l}\text { Gronn describes DL as a unit of analysis by which one } \\
\text { could understand leadership in a more holistic sense, } \\
\text { moving away from an individual or leader/follower } \\
\text { duality. Gronn (2000, 2002) argues that while leadership } \\
\text { may be shared in certain situations, this is not necessarily } \\
\text { a sufficient requirement for it to be considered distributed } \\
\text { (Bolden, 2011). More specifically, Gronn (2002) suggests } \\
\text { that DL is composed of concertive action (spontaneous } \\
\text { collaboration of actors with different expertise) and } \\
\text { conjoined agency (the synchronization of leadership } \\
\text { action across individuals). While conjoined agency is a } \\
\text { feature of SL, there is a relative absence of concertive } \\
\text { action in its conceptualisation (Currie and Lockett 2011). } \\
\text { Thus, while there are clearly parallels between shared and } \\
\text { distributed leadership (Bennett et al. 2003), there are also } \\
\text { points of dissonance. }\end{array}$ \\
\hline Collective & $\begin{array}{l}\text { Contractor et } \\
\text { al. }(2012)\end{array}$ & $\begin{array}{l}\text { Similar to distributed leadership, collective leadership is a } \\
\text { way of describing a variety of concepts that take a more } \\
\text { holistic approach to the study of leadership. }\end{array}$ \\
\hline Co-leadership & $\begin{array}{l}\text { Vine et al. } \\
\text { (2008) }\end{array}$ & $\begin{array}{l}\text { Co-leadership is described as the process by which two } \\
\text { leaders in vertically contiguous positions share the } \\
\text { responsibilities of leadership. }\end{array}$ \\
\hline Emergent & Beck (1981) & $\begin{array}{l}\text { Leadership acquired through other people accepting and } \\
\text { supporting an unassigned individuals' behaviour. }\end{array}$ \\
\hline Collaborative & $\begin{array}{l}\text { Archer \& } \\
\text { Cameron } \\
\text { (2013) }\end{array}$ & $\begin{array}{l}\text { Working together in a co-ordinated way to deliver results } \\
\text { with others across a boundary. }\end{array}$ \\
\hline Multi-directional & $\begin{array}{l}\text { Edwards et al. } \\
\text { (2002) }\end{array}$ & $\begin{array}{l}\text { Deriving from the notion of leadership based on personal } \\
\text { power (e.g. charisma) where positional authority has little } \\
\text { impact. This enables one to have influence in a number of } \\
\text { directions. }\end{array}$ \\
\hline Rotated & $\begin{array}{l}\text { Erez et al. } \\
(2002)\end{array}$ & $\begin{array}{l}\text { Refers to the idea of self-managed teams and relies on } \\
\text { members of a group stepping forward to carry out } \\
\text { leadership functions in turns. }\end{array}$ \\
\hline Self-leadership & $\begin{array}{l}\text { Manz \& Sims } \\
(1986)\end{array}$ & $\begin{array}{l}\text { The act of leading oneself to perform intrinsically } \\
\text { motivating tasks (an individual level concept). }\end{array}$ \\
\hline
\end{tabular}




\section{Appendix B - Systematic Review Protocol}

\author{
Statement of the Research \\ Problem
}

Reviews of shared leadership tend to merge findings from commercial and non-commercial settings. It is not clear from the extant literature, how much we know about how shared leadership works in commercial settings, or how it might be different to other domains.

\section{Objectives of the Systematic Review}

- To synthesize findings on empirical studies of shared leadership in commercial settings, in order to establish what we know.

- To contribute to the development of an agenda for future research in the field of shared leadership.

\section{Strategy for Identifying} Relevant Studies

Electronic database search of empirical studies of shared leadership in commercial settings published in peer reviewed journals since 1995 .

Databases selected include: ABI Inform, Business Source Complete, Emerald and Science Direct as they contain publications relevant to business, management and social science fields generally.

PsychINFO was also searched to identify empirical studies which may have been classified under the field of organisational or work psychology.
To be found in title, abstract, or key words:

- Shared leadership

- Distributed leadership

- Empirical studies.

- Qualitative, quantitative and mixed research methodologies.

- Commercial organisational settings (profit-seeking)

- Student teams.

- Peer-reviewed journal articles.

- Only full-text articles.

- English language only.

- Published since 1995.

- Conceptual and working papers (review is focused on empirical findings to establish the knowledge drawn from studies in the field).

- Studies relating to shared or distributed leadership in educational, healthcare, sporting, political, religious or other non-commercial contexts (non-profit seeking).

- Clarity of the research question

- Appropriateness of the methodology employed

- Size of the sample selected,

- Specification of theoretical frameworks and measurement approaches

- Validity of the research findings 
Appendix C: Table 2 -Chronology of Empirical Studies of Shared Leadership in Commercial Settings 1995-Present

\begin{tabular}{|c|c|c|c|c|c|c|c|}
\hline Date & Authors & Purpose of the Study & Terms and Definitions & $\begin{array}{l}\text { Theoretical } \\
\text { Frameworks }\end{array}$ & $\begin{array}{l}\text { Research Design / } \\
\text { Measures }\end{array}$ & Context/Sample & Key Findings \\
\hline 1996 & $\begin{array}{l}\text { Avolio, Jung, Murry } \\
\text { and Sivasubramanium }\end{array}$ & $\begin{array}{l}\text { To assess the impact of } \\
\text { shared leadership (SL) on } \\
\text { team performance. }\end{array}$ & $\begin{array}{l}\text { No explicit definition } \\
\text { given (but SL viewed as } \\
\text { transformational } \\
\text { leadership manifested at } \\
\text { the group level in highly } \\
\text { developed teams). }\end{array}$ & $\begin{array}{l}\text { Aggregation: Team } \\
\text { Multifactor Leadership } \\
\text { Questionnaire (TMLQ) } \\
\text { aggregated to the team } \\
\text { level. }\end{array}$ & $\begin{array}{l}\text { Quantitative: Survey } \\
\text { of self-reported } \\
\text { ratings of team } \\
\text { effectiveness. }\end{array}$ & $\begin{array}{l}\text { Undergraduate } \\
\text { student teams }\end{array}$ & $\begin{array}{l}\text { Shared leadership has a } \\
\text { positive impact on team } \\
\text { performance (SL related to } \\
\text { team members' willingness to } \\
\text { put in extra effort on the } \\
\text { project). }\end{array}$ \\
\hline 2001 & Pearce and Ensley & $\begin{array}{l}\text { To explores links between } \\
\text { shared strategic cognition } \\
\text { in top management teams } \\
\text { and new venture } \\
\text { performance. }\end{array}$ & None given. & Aggregation & $\begin{array}{l}\text { Quantitative: single } \\
\text { survey. }\end{array}$ & $\begin{array}{l}\text { Entrepreneurial } \\
\text { top management } \\
\text { teams across a } \\
\text { wide variety of } \\
\text { industries in US. }\end{array}$ & $\begin{array}{l}\text { SL is more likely than vertical } \\
\text { leadership to lead to increased } \\
\text { revenue \& improved venture } \\
\text { growth rates. }\end{array}$ \\
\hline 2002 & Pearce and Sims & $\begin{array}{l}\text { To investigate vertical } \\
\text { versus shared leadership } \\
\text { as predictors of the } \\
\text { effectiveness of change } \\
\text { management teams. }\end{array}$ & $\begin{array}{l}\text { Distributed influence } \\
\text { from within the team. } \\
\text { Lateral influence among } \\
\text { peers. }\end{array}$ & $\begin{array}{l}\text { Aggregation (ratings } \\
\text { aggregated to team level } \\
\text { for five leadership } \\
\text { strategies: aversive } \\
\text { directive, transactional, } \\
\text { transformational and } \\
\text { empowering). }\end{array}$ & $\begin{array}{l}\text { Quantitative: Self- } \\
\text { reported and manager } \\
\text { ratings of seven } \\
\text { effectiveness } \\
\text { dimensions. }\end{array}$ & $\begin{array}{l}71 \text { automobile } \\
\text { change } \\
\text { management } \\
\text { teams in one } \\
\text { organisational } \\
\text { setting }\end{array}$ & $\begin{array}{l}\text { Shared leadership is a more } \\
\text { useful predictor of team } \\
\text { effectiveness than vertical } \\
\text { leadership (SL significantly } \\
\text { related to increased } \\
\text { citizenship and networking } \\
\text { behaviour). }\end{array}$ \\
\hline 2002 & $\begin{array}{l}\text { Sivasubramanium, } \\
\text { Murry, Avolio and } \\
\text { Jung }\end{array}$ & $\begin{array}{l}\text { To explore how team } \\
\text { leadership predicts levels } \\
\text { of group potency and } \\
\text { group performance over } \\
\text { time. }\end{array}$ & $\begin{array}{l}\text { Collective influence of } \\
\text { members in a team on } \\
\text { each other. }\end{array}$ & $\begin{array}{l}\text { Aggregation (TMLQ } \\
\text { aggregated to the team } \\
\text { level) }\end{array}$ & $\begin{array}{l}\text { Quantitative: Self- } \\
\text { ratings and instructor } \\
\text { assigned grades }\end{array}$ & $\begin{array}{l}42 \text { teams of } 182 \\
\text { undergraduate } \\
\text { students in a US } \\
\text { University. }\end{array}$ & $\begin{array}{l}\text { Groups rating themselves high } \\
\text { on shared transformational } \\
\text { leadership behaviours soon } \\
\text { after group formation saw } \\
\text { themselves as more potent } \\
\text { over time and also achieving } \\
\text { higher performance. }\end{array}$ \\
\hline 2002 & $\begin{array}{l}\text { Waldersee and } \\
\text { Eagleson }\end{array}$ & $\begin{array}{l}\text { To examine whether SL is } \\
\text { more effective than VL } \\
\text { during strategic } \\
\text { reorientations. }\end{array}$ & $\begin{array}{l}\text { The sharing of leadership } \\
\text { functions across those } \\
\text { responsible for the } \\
\text { implementation of } \\
\text { change. }\end{array}$ & Not identified. & Observation. & $\begin{array}{l}\text { A hotel } \\
\text { corporation } \\
\text { introducing a re- } \\
\text { orientation at } 42 \\
\text { of its hotels. } \\
\end{array}$ & $\begin{array}{l}\text { Where SL was present ( } 1 / 3 \text { of } \\
\text { hotels studied), the hotels } \\
\text { were perceived to have been } \\
\text { more successful at } \\
\text { implementing change. }\end{array}$ \\
\hline 2006 & $\begin{array}{l}\text { Mehra, Smith, Dixon } \\
\text { and Robertson }\end{array}$ & $\begin{array}{l}\text { To investigate how the } \\
\text { network structure of } \\
\text { leadership perceptions is } \\
\text { related to team } \\
\text { performance. }\end{array}$ & $\begin{array}{l}\text { Shared, distributed } \\
\text { phenomenon in which } \\
\text { there can be several } \\
\text { formally appointed and/or } \\
\text { emergent leaders. }\end{array}$ & $\begin{array}{l}\text { Social Network Theory } \\
\text { (Centralization) }\end{array}$ & $\begin{array}{l}\text { Qualitative: coding } \\
\text { based on visual } \\
\text { analysis of leadership } \\
\text { network diagrams }\end{array}$ & $\begin{array}{l}28 \text { financial } \\
\text { services sales } \\
\text { teams }\end{array}$ & $\begin{array}{l}\text { Supports the view that certain } \\
\text { kinds of decentralized } \\
\text { leadership structures are } \\
\text { associated with better team } \\
\text { performance than others. }\end{array}$ \\
\hline
\end{tabular}




\begin{tabular}{|c|c|c|c|c|c|c|c|}
\hline 2006 & $\begin{array}{l}\text { Ensley, Hmieleski and } \\
\text { Pearce }\end{array}$ & $\begin{array}{l}\text { To investigate the relative } \\
\text { influence of vertical } \\
\text { versus shared leadership } \\
\text { within new venture top } \\
\text { management teams on the } \\
\text { performance of start-ups. }\end{array}$ & $\begin{array}{l}\text { Team process where } \\
\text { leadership is carried out } \\
\text { by the team as a whole } \\
\text { rather than solely by a } \\
\text { single designated } \\
\text { individual. }\end{array}$ & $\begin{array}{l}\text { Aggregation (Ratings } \\
\text { on behavioural scales } \\
\text { for four leadership } \\
\text { strategies: directive, } \\
\text { transactional, } \\
\text { transformational, \& } \\
\text { empowering aggregated } \\
\text { to team). }\end{array}$ & $\begin{array}{l}\text { Analysis of growth } \\
\text { index for new } \\
\text { ventures }\end{array}$ & $\begin{array}{l}\text { New venture top } \\
\text { management } \\
\text { teams }\end{array}$ & $\begin{array}{l}\text { Shared leadership was found } \\
\text { to be a particularly important } \\
\text { predictor of new venture } \\
\text { performance (it takes an array } \\
\text { of talented individuals to grow } \\
\text { new ventures). }\end{array}$ \\
\hline 2006 & $\begin{array}{l}\text { Carte, Chidambaram } \\
\text { and Becker }\end{array}$ & $\begin{array}{l}\text { To provide insights into } \\
\text { whether/how emergent } \\
\text { leadership impacts team } \\
\text { performance and to } \\
\text { investigate which type of } \\
\text { leadership (concentrated } \\
\text { or shared) matters over } \\
\text { time. }\end{array}$ & $\begin{array}{l}\text { A collection of roles and } \\
\text { behaviours that can be } \\
\text { split, shared, and rotated } \\
\text { with multiple leaders } \\
\text { existing within a team at } \\
\text { any given time (Barry } \\
\text { 1991). }\end{array}$ & Not identified & $\begin{array}{l}\text { Longitudinal: content } \\
\text { analysis of electronic } \\
\text { messages exchanged } \\
\text { by members } \\
\text { of the virtual teams }\end{array}$ & $\begin{array}{l}22 \text { virtual student } \\
\text { teams completing } \\
\text { a semester-long } \\
\text { project in an } \\
\text { undergraduate } \\
\text { database course in } \\
\text { three US } \\
\text { universities. }\end{array}$ & $\begin{array}{l}\text { Of the leadership behaviour's } \\
\text { observed in the high- } \\
\text { performing teams, one - } \\
\text { Producer behaviour -was } \\
\text { concentrated; while another - } \\
\text { Monitor behaviour -was } \\
\text { shared. Further, leadership } \\
\text { behaviour's exhibited early in } \\
\text { the team's life were more } \\
\text { predictive of success than } \\
\text { those exhibited later. }\end{array}$ \\
\hline 2007 & $\begin{array}{l}\text { Carson, Tesluk and } \\
\text { Marrone }\end{array}$ & $\begin{array}{l}\text { To examine antecedent } \\
\text { conditions that lead to the } \\
\text { development of shared } \\
\text { leadership and the } \\
\text { influence of SL on team } \\
\text { performance. }\end{array}$ & $\begin{array}{l}\text { An emergent team } \\
\text { property that results from } \\
\text { the distribution of } \\
\text { leadership influence } \\
\text { across multiple team } \\
\text { members. }\end{array}$ & $\begin{array}{l}\text { Social Network Theory } \\
\text { (Density) }\end{array}$ & $\begin{array}{l}\text { Quantitative: surveys } \\
\text { from MBA consulting } \\
\text { students, clients and } \\
\text { faculty advisors. }\end{array}$ & $\begin{array}{l}59 \text { Consulting } \\
\text { Teams comprised } \\
\text { of MBA students }\end{array}$ & $\begin{array}{l}\text { Internal team environment } \\
\text { (shared purpose, voice, social } \\
\text { support) and external } \\
\text { coaching has a direct } \\
\text { relationship with SL. } \\
\text { Teams relying on multiple } \\
\text { members for leadership } \\
\text { performed better than those in } \\
\text { which internal leadership was } \\
\text { scarce. }\end{array}$ \\
\hline 2008 & Solansky & $\begin{array}{l}\text { To compare the } \\
\text { motivational, social and } \\
\text { cognitive effects of shared } \\
\text { v single leadership. }\end{array}$ & $\begin{array}{l}\text { Shared leadership } \\
\text { represents teams whose } \\
\text { members are empowered } \\
\text { to share the tasks and } \\
\text { responsibilities of } \\
\text { leadership (Ensley et al., } \\
\text { 2003). }\end{array}$ & $\begin{array}{l}\text { Social Network Theory } \\
\text { (Density) }\end{array}$ & $\begin{array}{l}\text { Quantitative: surveys } \\
\text { measuring collective } \\
\text { efficacy, relational } \\
\text { conflict and } \\
\text { transactive memory } \\
\text { system. } \\
\text { Qualitative - content } \\
\text { analysis of participant } \\
\text { diaries (journals) }\end{array}$ & $\begin{array}{l}20 \text { student teams } \\
\text { (undergraduate } \\
\text { management } \\
\text { class) at a large } \\
\text { US university. }\end{array}$ & $\begin{array}{l}\text { Teams in the study engaging } \\
\text { in shared leadership ( } 9 \text { out of } \\
20 \text { ) enjoy motivational, social } \\
\text { and cognitive advantages over } \\
\text { teams led by a single } \\
\text { individual ( } 11 \text { out of } 20 \text { ). }\end{array}$ \\
\hline 2010 & Hoch, Pearce and & To examine the & A collective social & Aggregation (Ratings & Quantitative: & 96 Dutch & SL predicted performance and \\
\hline
\end{tabular}




\begin{tabular}{|c|c|c|c|c|c|c|c|}
\hline & Welzel & $\begin{array}{l}\text { moderating effects of age } \\
\text { diversity and team } \\
\text { co-ordination on the } \\
\text { relationship between } \\
\text { shared leadership and } \\
\text { team performance. }\end{array}$ & $\begin{array}{l}\text { influence process shared } \\
\text { by team members and } \\
\text { aimed toward the } \\
\text { achievement of one or } \\
\text { more common goals. }\end{array}$ & $\begin{array}{l}\text { for transformational, } \\
\text { transactional, directive, } \\
\text { empowering and } \\
\text { aversive leadership } \\
\text { behaviour }\end{array}$ & $\begin{array}{l}\text { Questionnaire } \\
\text { measuring both } \\
\text { shared leadership and } \\
\text { vertical leadership in } \\
\text { teams }\end{array}$ & $\begin{array}{l}\text { individuals in } 26 \\
\text { teams in a } \\
\text { German } \\
\text { consulting firm }\end{array}$ & $\begin{array}{l}\text { both age diversity and } \\
\text { coordination in teams } \\
\text { moderated the impact of SL } \\
\text { on teams' performance. SL } \\
\text { positively related to team } \\
\text { performance when age } \\
\text { diversity and level of } \\
\text { coordination were low. }\end{array}$ \\
\hline 2010 & Acar & $\begin{array}{l}\text { To analyse the interplay } \\
\text { between diversity and } \\
\text { emotional conflict across } \\
\text { time; and the role of SL in } \\
\text { moderating the } \\
\text { relationship between } \\
\text { diversity and emotional } \\
\text { conflict. }\end{array}$ & $\begin{array}{l}\text { Shared leadership refers } \\
\text { to the sharing of } \\
\text { leadership roles, } \\
\text { responsibilities, and } \\
\text { functions among all group } \\
\text { members }\end{array}$ & $\begin{array}{l}\text { Multiple theoretical } \\
\text { perspectives including } \\
\text { social identity theory, } \\
\text { self-categorization } \\
\text { theory, similarity- } \\
\text { attraction framework, } \\
\text { exchange theory. }\end{array}$ & $\begin{array}{l}\text { Longitudinal. } \\
\text { Quantitative: } \\
\text { questionnaires to } \\
\text { measure perceptions } \\
\text { of diversity, levels of } \\
\text { emotional conflict and } \\
\text { shared leadership. }\end{array}$ & $\begin{array}{l}81 \text { student groups } \\
\text { comprised of } 301 \\
\text { individual } \\
\text { students } \\
\text { (graduating } \\
\text { seniors) }\end{array}$ & $\begin{array}{l}\text { Shared leadership was found } \\
\text { to moderate the relationship } \\
\text { between diversity and } \\
\text { emotional conflict. }\end{array}$ \\
\hline 2010 & $\begin{array}{l}\text { Boies, Lvina and } \\
\text { Martens }\end{array}$ & $\begin{array}{l}\text { To examine the relations } \\
\text { between shared leadership } \\
\text { in teams, team trust, } \\
\text { potency, and } \\
\text { performance. }\end{array}$ & Not identified. & Aggregation. & $\begin{array}{l}\text { Quantitative: } \\
\text { questionnaires to } \\
\text { measure team } \\
\text { potency, trust and } \\
\text { shared leadership. }\end{array}$ & $\begin{array}{l}49 \text { teams of } 194 \\
\text { undergraduate } \\
\text { students } \\
\text { participating in a } \\
\text { business } \\
\text { simulation game. }\end{array}$ & $\begin{array}{l}\text { Team potency and trust are } \\
\text { positively related to shared } \\
\text { leadership. Team performance } \\
\text { did not always benefit from } \\
\text { shared transformational } \\
\text { leadership. }\end{array}$ \\
\hline 2010 & Small and Rentsch & $\begin{array}{l}\text { To explore trust and team } \\
\text { collectivism as } \\
\text { antecedents of shared } \\
\text { leadership. }\end{array}$ & $\begin{array}{l}\text { An emergent team } \\
\text { process defined by the } \\
\text { distribution of leadership } \\
\text { functions among multiple } \\
\text { team members. }\end{array}$ & $\begin{array}{l}\text { Social Network } \\
\text { Analysis } \\
\text { (Centralization). }\end{array}$ & $\begin{array}{l}\text { Longitudinal. } \\
\text { Quantitative: TMLQ } \\
\text { and Leader Behaviour } \\
\text { Description } \\
\text { Questionnaire } \\
\text { (LBDQ) } \\
\text { Qualitative: Coach's } \\
\text { assessment }\end{array}$ & $\begin{array}{l}280 \text { Business } \\
\text { students in } 60 \\
\text { teams in US } \\
\text { University }\end{array}$ & $\begin{array}{l}\text { SL is positively related to } \\
\text { team performance and SL is } \\
\text { likely to be higher when teams } \\
\text { are fully developed (SL } \\
\text { increases over time). } \\
\text { Antecedent conditions of SL } \\
\text { are trust and team } \\
\text { collectivism. }\end{array}$ \\
\hline 2010 & Cater and Justis & $\begin{array}{l}\text { To better understand the } \\
\text { conditions and factors } \\
\text { which affect the } \\
\text { development and } \\
\text { implementation of shared } \\
\text { leadership in multi- } \\
\text { generational family } \\
\text { businesses (MGFBs). }\end{array}$ & $\begin{array}{l}\text { SL in a family firm is } \\
\text { characterised by 'sibling } \\
\text { partnerships or cousin } \\
\text { consortiums' - SL is } \\
\text { present when the siblings } \\
\text { in a sibling partnership } \\
\text { form a team with no } \\
\text { single individual as the } \\
\text { leader. }\end{array}$ & $\begin{array}{l}\text { Exploratory, theory } \\
\text { building approach. }\end{array}$ & $\begin{array}{l}\text { Qualitative case study } \\
\text { approach using in- } \\
\text { depth interviews. }\end{array}$ & $\begin{array}{l}\text { Top managers of } \\
\text { four multi- } \\
\text { generational } \\
\text { family businesses } \\
\text { (MGFBs) }\end{array}$ & $\begin{array}{l}\text { Long-term orientation and } \\
\text { close communication enhance } \\
\text { SL. Resistance to change, } \\
\text { failure to release control and } \\
\text { reporting relationship } \\
\text { confusion negatively impact } \\
\text { SL. Increased decision time } \\
\text { countered by higher decision } \\
\text { quality. }\end{array}$ \\
\hline 2011 & Gupta, Huang and & To examine the & Leadership as a collective & Aggregation approach. & Quantitative - & Sample of 35 & The effect of social capital on \\
\hline
\end{tabular}




\begin{tabular}{|c|c|c|c|c|c|c|c|}
\hline & Yayla & $\begin{array}{l}\text { moderating impact of } \\
\text { collective } \\
\text { transformational } \\
\text { leadership (CTL) on the } \\
\text { relationship between } \\
\text { social capital \& } \\
\text { performance. }\end{array}$ & $\begin{array}{l}\text { process, such that the } \\
\text { team influences, inspires } \\
\text { and motivates team } \\
\text { members. }\end{array}$ & & $\begin{array}{l}\text { questionnaires to } \\
\text { measure teams } \\
\text { capability for } \\
\text { collectively engaging } \\
\text { in transformational } \\
\text { leadership behaviours. }\end{array}$ & $\begin{array}{l}\text { (senior business) } \\
\text { student teams } \\
\text { making } \\
\text { managerial } \\
\text { decisions in a } \\
\text { simulated athletic } \\
\text { footwear industry }\end{array}$ & $\begin{array}{l}\text { performance is contingent on } \\
\text { transformational leadership } \\
\text { collectively enacted by the } \\
\text { team. }\end{array}$ \\
\hline 2011 & $\begin{array}{l}\text { Ocker, Huang, } \\
\text { Benbunan-Fich and } \\
\text { Hiltz }\end{array}$ & $\begin{array}{l}\text { To investigate the effects } \\
\text { of distance and team } \\
\text { configuration on } \\
\text { leadership in partially } \\
\text { distributed virtual teams } \\
\text { (PDTs) }\end{array}$ & $\begin{array}{l}\text { Leadership functions } \\
\text { shared between team } \\
\text { members. }\end{array}$ & Not identified. & $\begin{array}{l}\text { Field experiment - } \\
\text { using primarily } \\
\text { qualitative sources of } \\
\text { data (observation). }\end{array}$ & $\begin{array}{l}12 \text { student teams, } \\
\text { in } 3 \text { sites engaged } \\
\text { in a semester long } \\
\text { project for a } \\
\text { corporate sponsor. }\end{array}$ & $\begin{array}{l}\text { Teams with SL exhibited an } \\
\text { advanced awareness of } \\
\text { member capabilities, better } \\
\text { utilization of their members, } \\
\text { which positively impacted } \\
\text { performance. }\end{array}$ \\
\hline 2012 & Ishikawa & $\begin{array}{l}\text { To consider the effects of } \\
\text { SL on R\&D team } \\
\text { performance; and to } \\
\text { consider the effects of } \\
\text { transformational and } \\
\text { gatekeeping leadership of } \\
\text { formal leaders on SL. }\end{array}$ & $\begin{array}{l}\text { An emergent team } \\
\text { property resulting from } \\
\text { the distribution of } \\
\text { leadership influence } \\
\text { across multiple team } \\
\text { members (Carson et al., } \\
\text { 2007). }\end{array}$ & $\begin{array}{l}\text { Social Network Theory } \\
\text { (Density) }\end{array}$ & $\begin{array}{l}\text { Quantitative }-. \\
\text { Transformational } \\
\text { leadership measured } \\
\text { using MLQ; } \\
\text { gatekeeping } \\
\text { leadership behaviour } \\
\text { measured on a five- } \\
\text { point response scale. }\end{array}$ & $\begin{array}{l}654 \text { team } \\
\text { members grouped } \\
\text { into } 119 \text { teams in } \\
6 \text { Japanese } \\
\text { industrial } R \& D \\
\text { teams; and } 26 \\
\text { team managers. }\end{array}$ & $\begin{array}{l}\text { SL positively influences team } \\
\text { performance. } \\
\text { Transformational leadership } \\
\text { tends to increase the norm for } \\
\text { maintaining consensus, which } \\
\text { in turn has a negative effect on } \\
\text { shared leadership. }\end{array}$ \\
\hline 2012 & $\begin{array}{l}\text { Muethel, Gehrlein and } \\
\text { Hoegl }\end{array}$ & $\begin{array}{l}\text { To investigate the } \\
\text { relationship between } \\
\text { shared leadership } \\
\text { behaviours and team } \\
\text { performance in dispersed } \\
\text { teams (also considers } \\
\text { team composition from } \\
\text { point of view of socio- } \\
\text { demographic factors). }\end{array}$ & $\begin{array}{l}\text { 'A dynamic, interactive } \\
\text { influence process among } \\
\text { individuals of a group for } \\
\text { which the objective is to } \\
\text { lead one another to the } \\
\text { achievement of group or } \\
\text { organizational goals or } \\
\text { both' (Conger and Pearce, } \\
\text { 2003: 1). }\end{array}$ & $\begin{array}{l}\text { Aggregation (each } \\
\text { individual rates the } \\
\text { group on attributes } \\
\text { defined at that level) }\end{array}$ & $\begin{array}{l}\text { Quantitative - online } \\
\text { questionnaire of team } \\
\text { leaders and team } \\
\text { members }\end{array}$ & $\begin{array}{l}96 \text { dispersed } \\
\text { software } \\
\text { development } \\
\text { teams from } 36 \\
\text { companies. }\end{array}$ & $\begin{array}{l}\text { SL behaviours can foster } \\
\text { performance in dispersed } \\
\text { teams. Team composition } \\
\text { featuring a high female-to- } \\
\text { male ratio and high national } \\
\text { diversity are drivers of SL in } \\
\text { virtual team contexts. A high } \\
\text { mean age was an impediment } \\
\text { to SL in this context. }\end{array}$ \\
\hline 2012 & $\begin{array}{l}\text { Bergman, Small, } \\
\text { Rentsch, and } \\
\text { Bergman }\end{array}$ & $\begin{array}{l}\text { To examine the process of } \\
\text { shared leadership in } \\
\text { decision-making teams; } \\
\text { and the impact of SL on } \\
\text { consensus, conflict, } \\
\text { intragroup trust, and } \\
\text { cohesion. }\end{array}$ & $\begin{array}{l}\text { Shared leadership viewed } \\
\text { as the number of members } \\
\text { contributing } \\
\text { behaviourally to the } \\
\text { leadership of the team. }\end{array}$ & $\begin{array}{l}\text { Social Network Theory } \\
\text { (Density - measured } \\
\text { leadership behaviours } \\
\text { exhibited by each team } \\
\text { member). }\end{array}$ & $\begin{array}{l}\text { Behavioural } \\
\text { Observation (rated on } \\
\text { BARS) in laboratory } \\
\text { setting. }\end{array}$ & $\begin{array}{l}180 \\
\text { undergraduate } \\
\text { students in a US } \\
\text { university } \\
\text { organised into } 45 \\
\text { ad hoc decision } \\
\text { making teams. }\end{array}$ & $\begin{array}{l}\text { The likelihood of teams } \\
\text { experiencing a full range of } \\
\text { leadership behaviours } \\
\text { increases with SL. Teams } \\
\text { with SL experience less } \\
\text { conflict, greater consensus, } \\
\text { and higher intragroup trust } \\
\text { and cohesion than teams } \\
\text { without SL. }\end{array}$ \\
\hline 2012 & Erkutlu & $\begin{array}{l}\text { To examine whether } \\
\text { organizational culture }\end{array}$ & $\begin{array}{l}\text { An emergent team } \\
\text { property that results from }\end{array}$ & $\begin{array}{l}\text { Consensus ratings for } \\
\text { team proactivity }\end{array}$ & $\begin{array}{l}\text { Quantitative - } \\
\text { questionnaires. }\end{array}$ & $\begin{array}{l}420 \text { employees in } \\
105 \text { teams in } 21\end{array}$ & $\begin{array}{l}\text { SL in a work team is } \\
\text { positively related to team }\end{array}$ \\
\hline
\end{tabular}




\begin{tabular}{|c|c|c|c|c|c|c|c|}
\hline & & $\begin{array}{l}\text { moderates the relationship } \\
\text { between shared leadership } \\
\text { and team proactive } \\
\text { behaviour. }\end{array}$ & $\begin{array}{l}\text { the distribution of } \\
\text { leadership influence } \\
\text { across multiple team } \\
\text { members (Carson } \text { et al., } \\
\text { 2007). }\end{array}$ & $\begin{array}{l}\text { (Campion et al. 1993) } \\
\text { i.e. captured without } \\
\text { aggregation. } \\
\text { Culture and SL captured } \\
\text { via individual responses } \\
\text { aggregated to team } \\
\text { level. }\end{array}$ & & $\begin{array}{l}\text { commercial } \\
\text { Turkish banks. }\end{array}$ & $\begin{array}{l}\text { proactive behaviour. The } \\
\text { relationship of SL with team } \\
\text { proactivity is stronger in } \\
\text { organizations with higher } \\
\text { levels of supportive culture. }\end{array}$ \\
\hline 2013 & Patton and Higgs & $\begin{array}{l}\text { To analyse the role of } \\
\text { shared leadership in the } \\
\text { strategic decision making } \\
\text { processes of new } \\
\text { technology based firms. }\end{array}$ & $\begin{array}{l}\text { A concept where the firm } \\
\text { is directed by the actions } \\
\text { of multiple players } \\
\text { working together rather } \\
\text { than a single individual. }\end{array}$ & Not identified. & $\begin{array}{l}\text { Qualitative: Case } \\
\text { study approach }\end{array}$ & $\begin{array}{l}5 \text { Early stage } \\
\text { technology } \\
\text { businesses }\end{array}$ & $\begin{array}{l}\text { Evidence of considerable } \\
\text { collective activity in decision- } \\
\text { making through a process of } \\
\text { negotiations; (little evidence } \\
\text { to suggest that the leadership } \\
\text { role rotated). }\end{array}$ \\
\hline 2013 & Hoch & $\begin{array}{l}\text { To investigate the } \\
\text { relationship between SL } \\
\text { and innovation as well as } \\
\text { antecedents of SL in } \\
\text { terms of employee } \\
\text { integrity and vertical } \\
\text { transformational and } \\
\text { empowering leadership. }\end{array}$ & $\begin{array}{l}\text { 'A dynamic interactive } \\
\text { influence process among } \\
\text { individuals in groups for } \\
\text { which the objective is to } \\
\text { lead one another to the } \\
\text { achievement of group or } \\
\text { organizational goals or } \\
\text { both' (Conger and Pearce, } \\
\text { 2003: 1). }\end{array}$ & $\begin{array}{l}\text { Direct consensus model } \\
\text { - team as a referent } \\
\text { (Chan 1998) }\end{array}$ & $\begin{array}{l}\text { Questionnaires to } \\
\text { measure SL } \\
\text { completed by team } \\
\text { members and } \\
\text { questionnaires to } \\
\text { measure VL styles } \\
\text { completed by team } \\
\text { leaders. }\end{array}$ & $\begin{array}{l}\text { Field sample of } \\
43 \text { work teams } \\
\text { comprising } 184 \\
\text { team members } \\
\text { involved in } \\
\text { product } \\
\text { development in } 2 \\
\text { different co.'s. }\end{array}$ & $\begin{array}{l}\text { Vertical transformational and } \\
\text { empowering leadership } \\
\text { enhances SL. SL is associated } \\
\text { with innovative behaviour. } \\
\text { Both vertical transformational } \\
\text { and empowering leadership } \\
\text { and team member integrity } \\
\text { function as antecedents of SL. }\end{array}$ \\
\hline 2013 & $\begin{array}{l}\text { Stagnaro and } \\
\text { Piotrowski }\end{array}$ & $\begin{array}{l}\text { To determine the actual } \\
\text { usage of SL in IT project } \\
\text { teams and assess the } \\
\text { views of IT Project } \\
\text { Managers toward SL. }\end{array}$ & $\begin{array}{l}\text { Shared leadership is a } \\
\text { dynamic process with } \\
\text { high levels of } \\
\text { collaboration, peer } \\
\text { influence and } \\
\text { demonstration of } \\
\text { leadership by a group as a } \\
\text { whole. }\end{array}$ & Not identified. & $\begin{array}{l}\text { Quantitative - Online } \\
\text { questionnaire }\end{array}$ & $\begin{array}{l}102 \text { IT project } \\
\text { managers in the } \\
\text { U.S. }\end{array}$ & $\begin{array}{l}\text { Positive attitudes and } \\
\text { sentiments toward a SL } \\
\text { perspective, on the part of IT } \\
\text { project managers, facilitates } \\
\text { the actual use of shared } \\
\text { leadership principles in } \\
\text { practice. }\end{array}$ \\
\hline 2013 & $\begin{array}{l}\text { Daspit, Tillman, Boyd } \\
\text { and McKee. }\end{array}$ & $\begin{array}{l}\text { To examine internal } \\
\text { factors of the team (team } \\
\text { environment, shared } \\
\text { leadership, and cohesion) } \\
\text { and the influence of each } \\
\text { factor on cross-functional } \\
\text { team (CFT) effectiveness. }\end{array}$ & $\begin{array}{l}\text { 'A dynamic, interactive } \\
\text { influence process among } \\
\text { individuals in teams for } \\
\text { which the objective is to } \\
\text { lead one another to the } \\
\text { achievement of team or } \\
\text { organizational goals or } \\
\text { both' (Conger and Pearce, } \\
\text { 2003: 1). }\end{array}$ & $\begin{array}{l}\text { Social Exchange } \\
\text { Theory ('individuals } \\
\text { who experience support } \\
\text { from their team will } \\
\text { experience an } \\
\text { obligation to repay the } \\
\text { team' p37.) }\end{array}$ & $\begin{array}{l}\text { Quantitative - } \\
\text { questionnaires to } \\
\text { assess students' } \\
\text { perceptions of internal } \\
\text { team environment, } \\
\text { shared leadership, } \\
\text { cohesion, and team } \\
\text { effectiveness. }\end{array}$ & $\begin{array}{l}142 \\
\text { undergraduate } \\
\text { students working } \\
\text { in } 24 \text { CFTs in a } \\
\text { US University. }\end{array}$ & $\begin{array}{l}\text { Members are more likely to } \\
\text { participate in SL roles when } \\
\text { they perceive higher levels of } \\
\text { shared purpose, social support } \\
\text { and voice. Team } \\
\text { effectiveness is enhanced } \\
\text { when individuals engage in } \\
\text { SL. In CFT's, cohesion is not } \\
\text { directly influenced by SL. }\end{array}$ \\
\hline 2013 & Huang & $\begin{array}{l}\text { To investigate the mutual } \\
\text { relationships among } \\
\text { shared leadership, } \\
\text { knowledge sharing, team }\end{array}$ & $\begin{array}{l}\text { Shared leadership is a } \\
\text { collective leadership by } \\
\text { the team members and is } \\
\text { described by collaborative }\end{array}$ & $\begin{array}{l}\text { Aggregation }-\mathrm{SL} \\
\text { aggregated to the team } \\
\text { level of analysis. }\end{array}$ & $\begin{array}{l}\text { Quantitative - Postal } \\
\text { questionnaires. }\end{array}$ & $\begin{array}{l}14 \text { SME's in } \\
\text { Taiwan } \\
\text { incorporating } 35 \\
\text { work teams (258 }\end{array}$ & $\begin{array}{l}\text { SL significantly and positively } \\
\text { affects team learning. } \\
\text { However, knowledge sharing } \\
\text { mediates the relationship }\end{array}$ \\
\hline
\end{tabular}




\begin{tabular}{|c|c|c|c|c|c|c|c|}
\hline & & $\begin{array}{l}\text { characteristics (size and } \\
\text { heterogeneity) and team } \\
\text { learning. }\end{array}$ & $\begin{array}{l}\text { decision-making and } \\
\text { shared responsibility for } \\
\text { outcomes (Hoch and } \\
\text { Dulebohn, 2013). }\end{array}$ & & & team members) & $\begin{array}{l}\text { between SL and team } \\
\text { learning. The relationship } \\
\text { between SL and team learning } \\
\text { is stronger when the team is } \\
\text { larger. }\end{array}$ \\
\hline 2013 & $\begin{array}{l}\text { Fausing, Jeppesen and } \\
\text { Jonsson. }\end{array}$ & $\begin{array}{l}\text { To explore the } \\
\text { moderating effects of } \\
\text { team work function } \\
\text { (manufacturing } v \\
\text { knowledge work) and } \\
\text { team autonomy on the } \\
\text { relationship between } \\
\text { shared leadership and } \\
\text { manager rated team } \\
\text { performance. }\end{array}$ & $\begin{array}{l}\text { Shared leadership is a } \\
\text { social, horizontal } \\
\text { influence process in } \\
\text { which leadership } \\
\text { emanates from and is } \\
\text { distributed among team } \\
\text { members. }\end{array}$ & $\begin{array}{l}\text { Aggregation - measures } \\
\text { were aggregated to the } \\
\text { team level and analyses } \\
\text { were conducted at the } \\
\text { team level. }\end{array}$ & $\begin{array}{l}\text { Quantitative - } \\
\text { electronic and paper } \\
\text { based questionnaires }\end{array}$ & $\begin{array}{l}81 \text { work teams } \\
\text { (incorporating } \\
552 \text { employees) in } \\
\text { a Danish } \\
\text { manufacturing } \\
\text { company. }\end{array}$ & $\begin{array}{l}\text { Work function significantly } \\
\text { moderates the relationships } \\
\text { between SL and team } \\
\text { performance. SL exhibited a } \\
\text { negative relationship with } \\
\text { manufacturing team } \\
\text { performance and a positive } \\
\text { relationship with knowledge } \\
\text { team performance. Team } \\
\text { autonomy is positively related } \\
\text { to performance and } \\
\text { significantly moderates the } \\
\text { relationship between SL and } \\
\text { team performance. }\end{array}$ \\
\hline 2014 & Hoch and Kozlowski & $\begin{array}{l}\text { To evaluate the impact of } \\
\text { traditional hierarchical } \\
\text { leadership, structural } \\
\text { supports, and shared team } \\
\text { leadership on the } \\
\text { performance of virtual } \\
\text { teams. }\end{array}$ & $\begin{array}{l}\text { SL describes a mutual } \\
\text { influence process, } \\
\text { characterized by } \\
\text { collaborative decision- } \\
\text { making and shared } \\
\text { responsibility, whereby } \\
\text { team members lead each } \\
\text { other toward the } \\
\text { achievement of goals. }\end{array}$ & $\begin{array}{l}\text { Aggregation - Team as } \\
\text { focal unit. (Ratings for } \\
\text { transformational, LMX, } \\
\text { career mentoring and } \\
\text { shared leadership } \\
\text { behaviours) }\end{array}$ & Quantitative & $\begin{array}{l}565 \text { team } \\
\text { members and } \\
\text { team leaders on } \\
101 \text { R\&D teams } \\
\text { from global } \\
\text { manufacturing } \\
\text { industries. }\end{array}$ & $\begin{array}{l}\text { The influence of hierarchical } \\
\text { leadership on team } \\
\text { performance is weakened } \\
\text { when teams are more virtual } \\
\text { in nature. Shared team } \\
\text { leadership was significantly } \\
\text { related to team performance } \\
\text { regardless of the degree of } \\
\text { virtuality. }\end{array}$ \\
\hline 2014 & $\begin{array}{l}\text { Liu, Hu, Zeng Wang, } \\
\text { Lin }\end{array}$ & $\begin{array}{l}\text { To explore whether and } \\
\text { how SL influences team } \\
\text { and individual learning. }\end{array}$ & $\begin{array}{l}\text { SL involves non- } \\
\text { hierarchical relationships } \\
\text { and describes a relational } \\
\text { phenomenon that is } \\
\text { characterised with a } \\
\text { dynamic, interactive } \\
\text { influence process among } \\
\text { individuals in the team. }\end{array}$ & $\begin{array}{l}\text { Social network } \\
\text { approach (density). }\end{array}$ & $\begin{array}{l}\text { Quantitative-online } \\
\text { questionnaire. }\end{array}$ & $\begin{array}{l}263 \text { members } \\
\text { from } 50 \text { teams in } \\
\text { China. }\end{array}$ & $\begin{array}{l}\text { SL has a positive influence on } \\
\text { individual and team learning } \\
\text { (promotes frequent } \\
\text { interaction, information and } \\
\text { knowledge exchange). }\end{array}$ \\
\hline
\end{tabular}




\begin{tabular}{|c|c|c|c|c|c|c|c|}
\hline 2014 & $\begin{array}{l}\text { Drescher, Korsgaard, } \\
\text { Welpe and Wigand }\end{array}$ & $\begin{array}{l}\text { To investigate whether } \\
\text { the expansion of SL } \\
\text { within groups is related to } \\
\text { growth in group trust; and } \\
\text { in turn, whether growth in } \\
\text { group trust is related to } \\
\text { performance } \\
\text { improvement. }\end{array}$ & $\begin{array}{l}\text { An emergent property of a } \\
\text { group where leadership } \\
\text { functions are distributed } \\
\text { among group members. }\end{array}$ & Not identified. & $\begin{array}{l}\text { Longitudinal: Trace } \\
\text { data from an online } \\
\text { simulation. }\end{array}$ & $\begin{array}{l}86 \text { groups } \\
\text { comprising } 849 \\
\text { individuals } \\
\text { participating in an } \\
\text { online strategy } \\
\text { simulation game } \\
\text { in Austria, } \\
\text { Germany and } \\
\text { Switzerland. }\end{array}$ & $\begin{array}{l}\text { As groups increasingly } \\
\text { distribute leadership functions } \\
\text { among group members, trust } \\
\text { grows. Through trust, the } \\
\text { expansion of shared } \\
\text { leadership is associated with } \\
\text { increased performance. }\end{array}$ \\
\hline 2014 & Jain and Jeppesen & $\begin{array}{l}\text { To measure employees' } \\
\text { attitude toward distributed } \\
\text { leadership (DL) practices } \\
\text { and investigate the } \\
\text { challenges involved in } \\
\text { implementing DL } \\
\text { practices in Indian } \\
\text { organizations. }\end{array}$ & $\begin{array}{l}\text { DL involves the } \\
\text { interaction of multiple } \\
\text { actors to achieve } \\
\text { organizational goals (Uhl- } \\
\text { Bien, 2006). }\end{array}$ & $\begin{array}{l}\text { Distributed cognition } \\
\text { and activity theory }\end{array}$ & $\begin{array}{l}\text { Qualitative - } \\
\text { unstructured personal } \\
\text { interviews and focus } \\
\text { group interviews. } \\
\text { Quantitative - } \\
\text { surveys. }\end{array}$ & $\begin{array}{l}180 \text { young mid- } \\
\text { level executives } \\
\text { from diverse } \\
\text { group of industry } \\
\text { sectors located in } \\
\text { Northern India. }\end{array}$ & $\begin{array}{l}\text { Indian managers believe DL } \\
\text { practices can enhance the } \\
\text { development of: taking } \\
\text { initiatives, accountability, } \\
\text { mutual respect, and promotion } \\
\text { of organisational efficiency } \\
\text { and effectiveness. Pre- } \\
\text { conditions for implementing } \\
\text { DL include: horizontal } \\
\text { structure, professionalism, } \\
\text { work commitment, power } \\
\text { sharing. }\end{array}$ \\
\hline 2014 & Hoch & $\begin{array}{l}\text { To examine the } \\
\text { association between } \\
\text { shared leadership and } \\
\text { team performance, the } \\
\text { moderating } \\
\text { role of demographic } \\
\text { diversity and the } \\
\text { mediating role of } \\
\text { information sharing on } \\
\text { this relationship }\end{array}$ & $\begin{array}{l}\text { 'A dynamic, interactive } \\
\text { influence process among } \\
\text { individuals in teams for } \\
\text { which the objective is to } \\
\text { lead one another to the } \\
\text { achievement of team or } \\
\text { organizational goals or } \\
\text { both' (Conger and Pearce, } \\
\text { 2003: 1). }\end{array}$ & Aggregation & Quantitative - survey & $\begin{array}{l}280 \text { team } \\
\text { members in } 46 \\
\text { teams from two } \\
\text { different } \\
\text { organizations. }\end{array}$ & $\begin{array}{l}\text { SL was positively associated } \\
\text { with team performance and } \\
\text { this association was mediated } \\
\text { by information sharing. } \\
\text { Demographic diversity } \\
\text { moderated the relationship } \\
\text { between SL and team } \\
\text { performance - SL was more } \\
\text { strongly associated with team } \\
\text { performance in more diverse } \\
\text { teams than in less diverse } \\
\text { teams. }\end{array}$ \\
\hline 2015 & $\begin{array}{l}\text { Mendez and } \\
\text { Busenbark }\end{array}$ & $\begin{array}{l}\text { To examine the effect of } \\
\text { shared leadership on the } \\
\text { gap between male and } \\
\text { female leadership } \\
\text { influence in groups. }\end{array}$ & $\begin{array}{l}\text { SL involves multiple } \\
\text { individuals collaborating } \\
\text { in a group's leadership } \\
\text { toward the attainment of } \\
\text { their common goals } \\
\text { (Conger and Pearce, } \\
\text { 2003). }\end{array}$ & $\begin{array}{l}\text { Social Network Theory } \\
\text { (Density) }\end{array}$ & $\begin{array}{l}\text { Quantitative - surveys } \\
\text { (administered during } \\
\text { committee meetings). }\end{array}$ & $\begin{array}{l}177 \text { participants in } \\
26 \text { committees } \\
\text { from different } \\
\text { industries in } \\
\text { southwest USA. }\end{array}$ & $\begin{array}{l}\text { SL has no significant } \\
\text { moderating effect on the } \\
\text { relationship between gender } \\
\text { and leadership influence, Men } \\
\text { are perceived to exhibit higher } \\
\text { leadership influence than } \\
\text { women and this gap is just as } \\
\text { prevalent with SL. }\end{array}$ \\
\hline 2015 & Fausing, Joensson, & To investigate antecedents & A 'simultaneous, ongoing, & Aggregated measure of & Quantitative - & Sample of 552 & External empowering team \\
\hline
\end{tabular}




\begin{tabular}{|c|c|c|c|c|c|c|c|}
\hline & $\begin{array}{l}\text { Lewandowski and } \\
\text { Bligh }\end{array}$ & of shared leadership & $\begin{array}{l}\text { mutual influence process } \\
\text { within a team that is } \\
\text { characterized by 'serial } \\
\text { emergence' of official as } \\
\text { well as unofficial leaders' } \\
\text { (Pearce, 2004: 48). }\end{array}$ & $\begin{array}{l}\text { transformational, } \\
\text { transactional, directive, } \\
\text { empowering and } \\
\text { aversive shared and } \\
\text { vertical leadership. }\end{array}$ & $\begin{array}{l}\text { Questionnaires } \\
\text { (administered online } \\
\text { and in paper form). }\end{array}$ & $\begin{array}{l}\text { employees in } 81 \\
\text { knowledge and } \\
\text { manufacturing } \\
\text { teams from one } \\
\text { Danish company. }\end{array}$ & $\begin{array}{l}\text { leadership and task and goal } \\
\text { interdependence significantly } \\
\text { predicted the extent of SL. SL } \\
\text { was positively related to team } \\
\text { leader ratings of team } \\
\text { performance. }\end{array}$ \\
\hline 2015 & Chreim & $\begin{array}{l}\text { To explore the different } \\
\text { leadership configurations } \\
\text { that can emerge when } \\
\text { different interactants enter } \\
\text { the leadership space and } \\
\text { to understand the } \\
\text { practices that result in } \\
\text { these configurations. }\end{array}$ & $\begin{array}{l}\text { Leadership is 'a } \\
\text { contextually embedded } \\
\text { process emerging from } \\
\text { the dynamic relationship } \\
\text { between various actors' } \\
\text { (Bolden et al. 2008: } 360 \text { ) }\end{array}$ & $\begin{array}{l}\text { Not explicit but focus } \\
\text { on relational practices } \\
\text { and dispersion of } \\
\text { leadership practices } \\
\text { suggests Social } \\
\text { Network Theory } \\
\text { (centralization) } \\
\text { approach. }\end{array}$ & $\begin{array}{l}\text { Qualitative - Case } \\
\text { study incorporating } \\
46 \text { semi-structured } \\
\text { interviews }\end{array}$ & $\begin{array}{l}46 \text { participants } \\
\text { (CEOs and Senior } \\
\text { Managers) in one } \\
\text { acquiring and four } \\
\text { acquired firms }\end{array}$ & $\begin{array}{l}\text { Different leadership } \\
\text { configurations can be co- } \\
\text { constructed by interactants in } \\
\text { a leadership space. Relational } \\
\text { practices play an important } \\
\text { role in shaping these } \\
\text { configurations. SL may be } \\
\text { advantageous or } \\
\text { disadvantageous. }\end{array}$ \\
\hline 2015 & $\begin{array}{l}\text { Zhou, Vredenburgh } \\
\text { and Rogoff }\end{array}$ & $\begin{array}{l}\text { To explore the } \\
\text { moderating effect of SL } \\
\text { on the relationship } \\
\text { between informational } \\
\text { diversity and } \\
\text { entrepreneurial team } \\
\text { diversity. }\end{array}$ & $\begin{array}{l}\text { 'A dynamic, interactive } \\
\text { influence process among } \\
\text { individuals in work group } \\
\text { in which the objective is } \\
\text { to lead one another to the } \\
\text { achieve group goals' } \\
\text { (Conger and Pearce, } \\
\text { 2003: 1). }\end{array}$ & $\begin{array}{l}\text { Social Network Theory } \\
\text { (Density) }\end{array}$ & $\begin{array}{l}\text { Quantitative - web- } \\
\text { based questionnaire }\end{array}$ & $\begin{array}{l}200 \\
\text { entrepreneurial } \\
\text { teams in a } \\
\text { technology } \\
\text { incubator in a } \\
\text { single university } \\
\text { in China. }\end{array}$ & $\begin{array}{l}\text { SL improves entrepreneurial } \\
\text { team performance and } \\
\text { moderates the relationship } \\
\text { between managerial skill } \\
\text { diversity and entrepreneurial } \\
\text { team performance (by } \\
\text { allowing different and } \\
\text { appropriate skills to emerge } \\
\text { and interact). }\end{array}$ \\
\hline 2015 & $\begin{array}{l}\text { Lee, Lee, Seo and } \\
\text { Choi }\end{array}$ & $\begin{array}{l}\text { To examine the influence } \\
\text { of SL and diversity on } \\
\text { knowledge sharing and } \\
\text { subsequently team } \\
\text { creativity. }\end{array}$ & $\begin{array}{l}\text { SL 'is a voluntarily, } \\
\text { informally emergent } \\
\text { structure beyond vertical } \\
\text { leadership' (Lee et al., } \\
\text { 2015: 47). }\end{array}$ & $\begin{array}{l}\text { Social Network Theory } \\
\text { (Density) }\end{array}$ & $\begin{array}{l}\text { Quantitative - } \\
\text { questionnaire survey }\end{array}$ & $\begin{array}{l}40 \text { student teams } \\
\text { of four to eight } \\
\text { members in an e- } \\
\text { learning } \\
\text { environment in a } \\
\text { South Korean } \\
\text { University. }\end{array}$ & $\begin{array}{l}\text { Shared leadership is a social } \\
\text { influence that affects } \\
\text { individual creativity. }\end{array}$ \\
\hline 2015 & $\begin{array}{l}\text { Mathieu, } \\
\text { Kukenberger, } \\
\text { D'Innocenzo and } \\
\text { Reilly }\end{array}$ & $\begin{array}{l}\text { To test whether team } \\
\text { cohesion and performance } \\
\text { are related reciprocally } \\
\text { over time; and to consider } \\
\text { the influence of team } \\
\text { members' competence } \\
\text { and degree of SL on team } \\
\text { performance. }\end{array}$ & $\begin{array}{l}\text { Horizontal leadership, } \\
\text { 'wherein members exert } \\
\text { influence on each other in } \\
\text { order to realize team } \\
\text { goals' (Mathieu et al., } \\
\text { 2015: 719). }\end{array}$ & $\begin{array}{l}\text { Social Network Theory } \\
\text { (Density) }\end{array}$ & $\begin{array}{l}\text { Longitudinal- } \\
\text { questionnaire survey }\end{array}$ & $\begin{array}{l}\text { Two samples: } \\
205 \text { students in } 57 \\
\text { teams in a US } \\
\text { university; } 214 \\
\text { students in } 64 \\
\text { teams at the same } \\
\text { US university (a } \\
\text { year later) }\end{array}$ & $\begin{array}{l}\text { SL did evolve over time and } \\
\text { remained a positive influence } \\
\text { on team cohesion throughout. } \\
\text { Supports a positive } \\
\text { association between SL and } \\
\text { team performance. }\end{array}$ \\
\hline 2016 & Serban and Roberts & $\begin{array}{l}\text { To examine the role of } \\
\text { task cohesion and team } \\
\text { ambiguity as antecedents }\end{array}$ & $\begin{array}{l}\text { A dynamic, interactive } \\
\text { influence process among } \\
\text { individuals in teams for }\end{array}$ & Not identified. & $\begin{array}{l}\text { Laboratory } \\
\text { experiment using } \\
\text { mixed methods - }\end{array}$ & $\begin{array}{l}120 \text { students in a } \\
\text { University in } \\
\text { England. }\end{array}$ & $\begin{array}{l}\text { Internal team environment and } \\
\text { task cohesion are predictors of } \\
\text { SL. Relationships between }\end{array}$ \\
\hline
\end{tabular}




\begin{tabular}{|c|c|c|c|c|c|c|c|}
\hline & & $\begin{array}{l}\text { of SL; and the role of task } \\
\text { satisfaction as an outcome } \\
\text { of SL. }\end{array}$ & $\begin{array}{l}\text { which the objective is to } \\
\text { lead one another to the } \\
\text { achievement of team or } \\
\text { organizational goals or } \\
\text { both' (Conger and Pearce, } \\
\text { 2003: 1). }\end{array}$ & & $\begin{array}{l}\text { quantitative and } \\
\text { qualitative }\end{array}$ & & $\begin{array}{l}\text { SL and team task satisfaction } \\
\text { are higher under a low task } \\
\text { ambiguity condition (SL can } \\
\text { produce higher satisfaction if } \\
\text { the task is clear). Failed to } \\
\text { support positive relationship } \\
\text { between SL and team } \\
\text { performance. }\end{array}$ \\
\hline 2017 & $\begin{array}{l}\text { Zhou and } \\
\text { Vredenburgh }\end{array}$ & $\begin{array}{l}\text { To investigate the } \\
\text { dispositional antecedents } \\
\text { of SL in Entrepreneurial } \\
\text { Teams (ETs) }\end{array}$ & $\begin{array}{l}\text { '..an emergent state on } \\
\text { ETs where } \\
\text { complementary leadership } \\
\text { influence flows among } \\
\text { team members in } \\
\text { response to particular } \\
\text { team strategic, task and } \\
\text { relational requirements' } \\
\text { (Zhou and Vrendenburgh, } \\
\text { 2017: 165). }\end{array}$ & $\begin{array}{l}\text { Social Network Theory } \\
\text { (Density) }\end{array}$ & $\begin{array}{l}\text { Cross-sectional, } \\
\text { quantitative. } \\
\text { Questionnaire (web- } \\
\text { based survey) }\end{array}$ & $\begin{array}{l}154 \text { ET's } \\
\text { (comprised of } 516 \\
\text { individual } \\
\text { entrepreneurs) in } \\
\text { a tech incubator in } \\
\text { China. }\end{array}$ & $\begin{array}{l}\text { Supports significant } \\
\text { relationship between team } \\
\text { conscientiousness \& openness } \\
\text { to experience and SL } \\
\text { emergence in ETs. } \\
\text { SL improves ET performance. }\end{array}$ \\
\hline
\end{tabular}


Appendix D: Nature of Non-Commercial Organisations included in the Review

\section{Nature of Non-Commercial Number of studies \\ Organisations Included in the Review reviewed}

\begin{tabular}{ll}
\hline Health & 9 \\
\hline Education & 7 \\
\hline Religious & 2 \\
\hline Civil service & 3 \\
\hline Defence forces & 1 \\
\hline Non-profit performing arts & 1 \\
\hline
\end{tabular}

\section{Total}


Table 1: Reading Guide

\begin{tabular}{ll}
\hline & Guide for Analytical Reading \\
\hline 1 & Year of publication \\
\hline 2 & Author(s) \\
\hline 3 & Purpose of the study \\
\hline 4 & Definition used \\
\hline 5 & Theoretical framework \\
\hline 6 & Research design/measures \\
\hline 7 & Context/sample \\
\hline 8 & Key findings \\
\hline
\end{tabular}

Table 1: Reading Guide 
Table 3 - Summary of Theoretical Frameworks and Measurement Approaches

\begin{tabular}{llll}
\hline $\begin{array}{l}\text { Theoretical } \\
\text { Frameworks }\end{array}$ & $\begin{array}{l}\text { Measurement } \\
\text { Approaches }\end{array}$ & $\begin{array}{l}\text { Samples: } \\
\text { Non-student v student }\end{array}$ & $\begin{array}{l}\text { Temporal } \\
\text { Nature }\end{array}$ \\
\hline $\begin{array}{l}\text { 15 Aggregation (38\%) } \\
\text { 13 Social network theory (32\%) }\end{array}$ & $\begin{array}{l}\text { 29 Quantitative (73\%) } \\
\text { 10 Qualitative (25\%) } \\
\text { 5 Others (13\%) }\end{array}$ & $\begin{array}{l}\text { 25 Non-student samples (62\%) } \\
\text { 1 Mixed methods (2\%) }\end{array}$ & 35 Cross-sectional (88\%) \\
7 Not identified (17\%) & & & 5 Longitudinal (12\%) \\
& & & \\
\hline
\end{tabular}

Table 3 - Summary of Theoretical Frameworks and Measurement Approaches 
Table 4: Impact of Shared Leadership on Team Performance by Sample Type

\begin{tabular}{llll}
\hline Sample & $\begin{array}{l}\text { No. of studies measuring } \\
\text { performance impact of } \\
\text { SL }\end{array}$ & $\begin{array}{l}\text { No. of studies reporting } \\
\text { positive impact on } \\
\text { performance }\end{array}$ & $\begin{array}{l}\text { \% of studies } \\
\text { reporting } \\
\text { positive impact } \\
\text { on performance }\end{array}$ \\
\hline $\begin{array}{l}\text { Combined (non-student } \\
\text { plus student samples) }\end{array}$ & 23 & 19 & $83 \%$ \\
\hline Non-student samples only & 14 & 12 & $86 \%$ \\
\hline Student samples only & 9 & 7 & $78 \%$ \\
\hline
\end{tabular}

Table 4 - Impact of Shared Leadership on Team Performance by Sample Type 


\section{Table 5: Comparisons with Other Settings}

\begin{tabular}{llll}
\hline Themes & $\begin{array}{l}\text { Commercial organizations } \\
\text { (COs) }\end{array}$ & Non-commercial Organizations (NCOs) & $\begin{array}{l}\text { Notable } \\
\text { Comparisons }\end{array}$ \\
\hline $\begin{array}{l}\text { Focus of } \\
\text { empirical }\end{array}$ & $\begin{array}{l}\text { Teams and team performance } \\
\text { research }\end{array}$ & $\begin{array}{l}\text { Health }- \text { organizational change, org } \\
\text { (Ulhoi and Muller, 2014). }\end{array}$ & $\begin{array}{l}\text { Belopder, institutional } \\
\text { implementation of SL. }\end{array}$ \\
& & $\begin{array}{l}\text { Education }- \text { new org structures; new ways } \\
\text { of organizing; learning through collective } \\
\text { ways of leading (Ulhoi and Muller, 2014) }\end{array}$
\end{tabular}

\begin{tabular}{ll}
\hline Concept of SL & $\begin{array}{l}\text { Predominantly informal, } \\
\text { lateral influence among peers } \\
\text { (Pearce and Sims 2002). }\end{array}$
\end{tabular}

(Pearce and Sims 2002).
Formal and informal - leadership practice stretched across formal leaders, followers and the situation (Spillane et al. 2004).
More planned and integrated approach in NCOs. Limited evidence regarding interplay between vertical leadership (VL) and SL in COs.

Few insights into mechanisms underlying SL in COs.

\begin{abstract}
Antecedents
Employee characteristics:

Employee commitment (Jain and Jeppesen 2014); integrity (Hoch 2014); conscientiousness, openness to experience (Zhou and Vredenburgh 2017).
\end{abstract}

Interdependence - reciprocal, pooled and sequential (Spillane et al. 2004); dynamic delegation (Klein et al. 2006); processes of inter-individual exchange or collaborative interaction (networking, collaborating \& knowledge-sharing), (Buchanan et al. 2007); continuous education/training in SL (Jackson 2000).
Employee commitment and commitment to SL principles (internalisation of SL concepts) (Jackson 2000).
Limited evidence of employee characteristics facilitating SL in NCOs. More progress in COs in this regard.

Subtle differences in conceptualization of a team. Broader range of stakeholders considered in NCOs.

Similar antecedents in the internal team environment in both COs and NCOs importance of shared goals and interdependence.

al, 2015); task cohesion (Serban and Roberts 2016).

External team Empowering managers (Hoch environment: 2014; Fausing et al. 2015); supportive culture (Erkutlu 2012); power-sharing norms and horizontal structure (Jain and Jeppesen 2014).
Social harmony, team affinity, shared goals (Jackson 2000); team identity, voice (Slantcheva-Durst 2014); trust (Eckel and Kezar, 2003; James et al. 2007; Greenfield et al 2009); interdependence (Spillane et al. 2004).

Empowerment, sharing culture, team-based structures \& processes (Slantcheva-Durst 2014); management support for SL, collaborative structures (Jackson 2000); supportive culture (Wood 2005); permission to select partnerships (Greenfield et al. 2009).
Similar antecedents in external team environment in both COs and NCOs. Importance of empowering managers. 


\begin{tabular}{|c|c|c|c|}
\hline Themes & $\begin{array}{l}\text { Commercial Organizations } \\
\text { (COs) }\end{array}$ & Non-commercial Organizations (NCOs) & $\begin{array}{l}\text { Notable } \\
\text { Comparisons }\end{array}$ \\
\hline $\begin{array}{l}\text { External } \\
\text { organizational } \\
\text { environment: }\end{array}$ & No evidence from COs. & $\begin{array}{l}\text { Supportive government policies and } \\
\text { initiatives, low regulatory pressures for } \\
\text { performance, high levels of social affluence } \\
\text { (Currie \& Lockett 2011). }\end{array}$ & $\begin{array}{l}\text { Lack of evidence } \\
\text { regarding how factors } \\
\text { in the external } \\
\text { micro/macro } \\
\text { environment impact } \\
\text { SL in COs. }\end{array}$ \\
\hline Moderators & $\begin{array}{l}\text { Work function, autonomy } \\
\text { level (Fausing et al. 2013); } \\
\text { task complexity (Hoch 2014, } \\
\text { Wang et al. 2014). }\end{array}$ & No evidence from NCOs. & $\begin{array}{l}\text { Suggests contingency } \\
\text { approach to } \mathrm{SL} \\
\text { required in COs } \\
\text { while more universal } \\
\text { application suggested } \\
\text { in NCOs. }\end{array}$ \\
\hline Mediators & $\begin{array}{l}\text { Social integration (Avolio et } \\
\text { al. 1996); citizenship (Pearce } \\
\text { and Sims, 2002); networking } \\
\text { (Pearce and Sims, 2002); } \\
\text { increased awareness of team } \\
\text { member capabilities (Ocker et } \\
\text { al. 2011); information sharing } \\
\text { (Hoch, 2013); knowledge } \\
\text { sharing (Huang, 2013). }\end{array}$ & $\begin{array}{l}\text { Enhanced peer collaboration (James et al. } \\
\text { 2007); participative \& innovative culture } \\
\text { (Buchanan et al. 2007); enhanced dynamic } \\
\text { capabilities of the org. (Reid \& } \\
\text { Karambayya, 2009); enhanced mental } \\
\text { health of team members (Haward et al., } \\
\text { 2003). }\end{array}$ & $\begin{array}{l}\text { Some similarity in } \\
\text { relation to mediators } \\
\text { in COs and NCOs at } \\
\text { team level. } \\
\text { Additional mediators } \\
\text { identified r at } \\
\text { individual and } \\
\text { organizational levels } \\
\text { in NCOs. }\end{array}$ \\
\hline Outcomes & $\begin{array}{l}\text { Team performance (Avolio et } \\
\text { al. 1996; Pearce and Ensley } \\
\text { 2001; Carson et al. 2007). } \\
\text { Team effectiveness (Acar, } \\
\text { 2010) arising from enhanced } \\
\text { team creativity (Lee et al. } \\
\text { 2015); higher intragroup trust } \\
\text { and team cohesion (Bergman } \\
\text { et al. 2012), (Mathieu et al. } \\
\text { 2015); team learning (Huang, } \\
\text { 2013). }\end{array}$ & $\begin{array}{l}\text { Improved performance (Hiller et al. 2006); } \\
\text { increased employee commitment (Hulpia et } \\
\text { al. 2010), increased job satisfaction (Wood } \\
\text { and Fields 2007); employee involvement } \\
\text { and greater empowerment (Klakovich, } \\
\text { 1996; Upenieks, 2000); flow and creativity } \\
\text { (Hooker and Csikszentmihalyi 2003). }\end{array}$ & $\begin{array}{l}\text { Predominant focus in } \\
\text { COs is team } \\
\text { performance. Some } \\
\text { evidence of this in } \\
\text { NCOs though not to } \\
\text { the same extent. }\end{array}$ \\
\hline
\end{tabular}




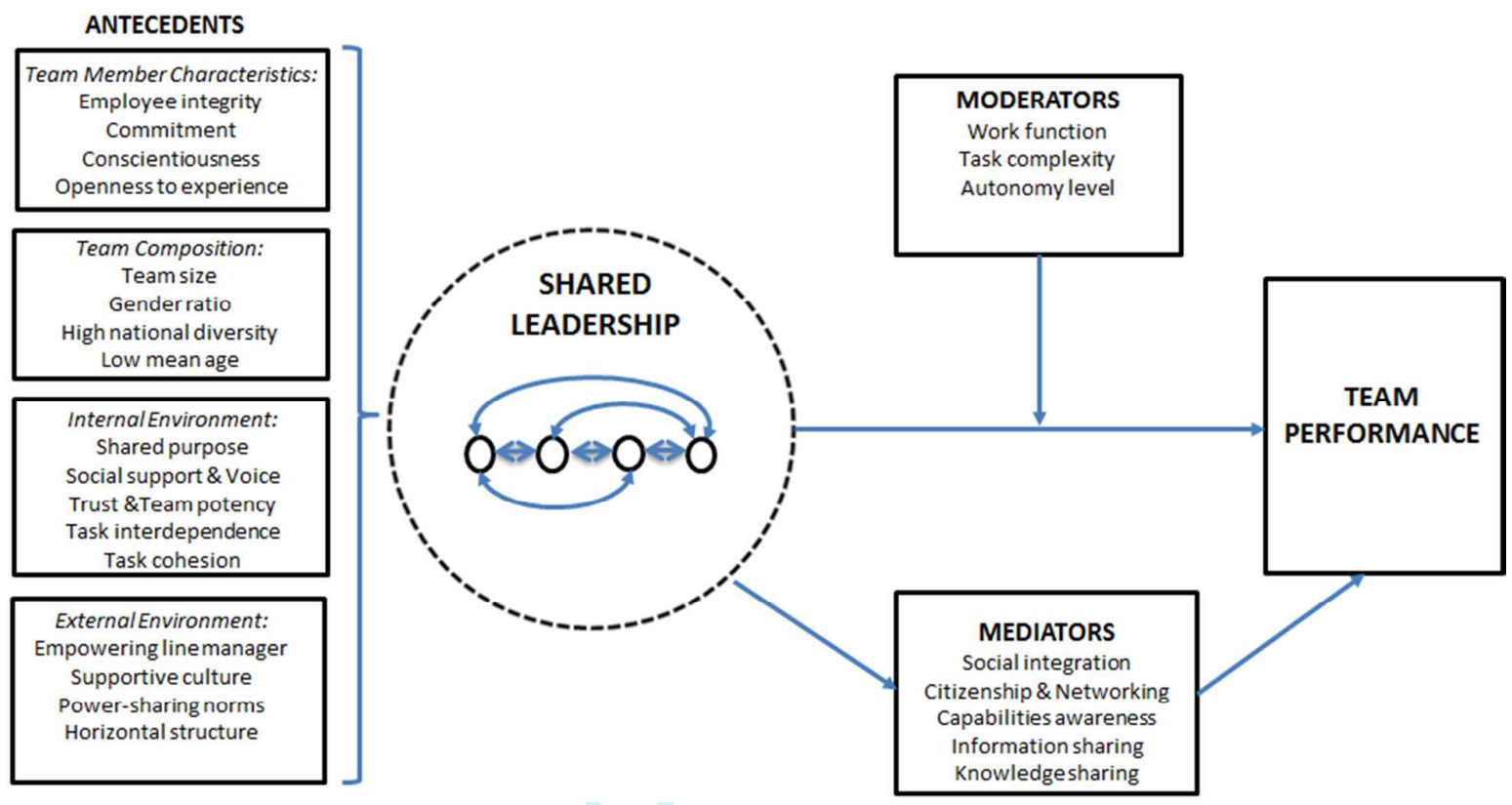

Fig. 1: Framework of Current Research - Antecedents, Moderators and Mediators of Shared Leadership and Team Performance. 
Fig. 2: Proposing a Future Research Agenda

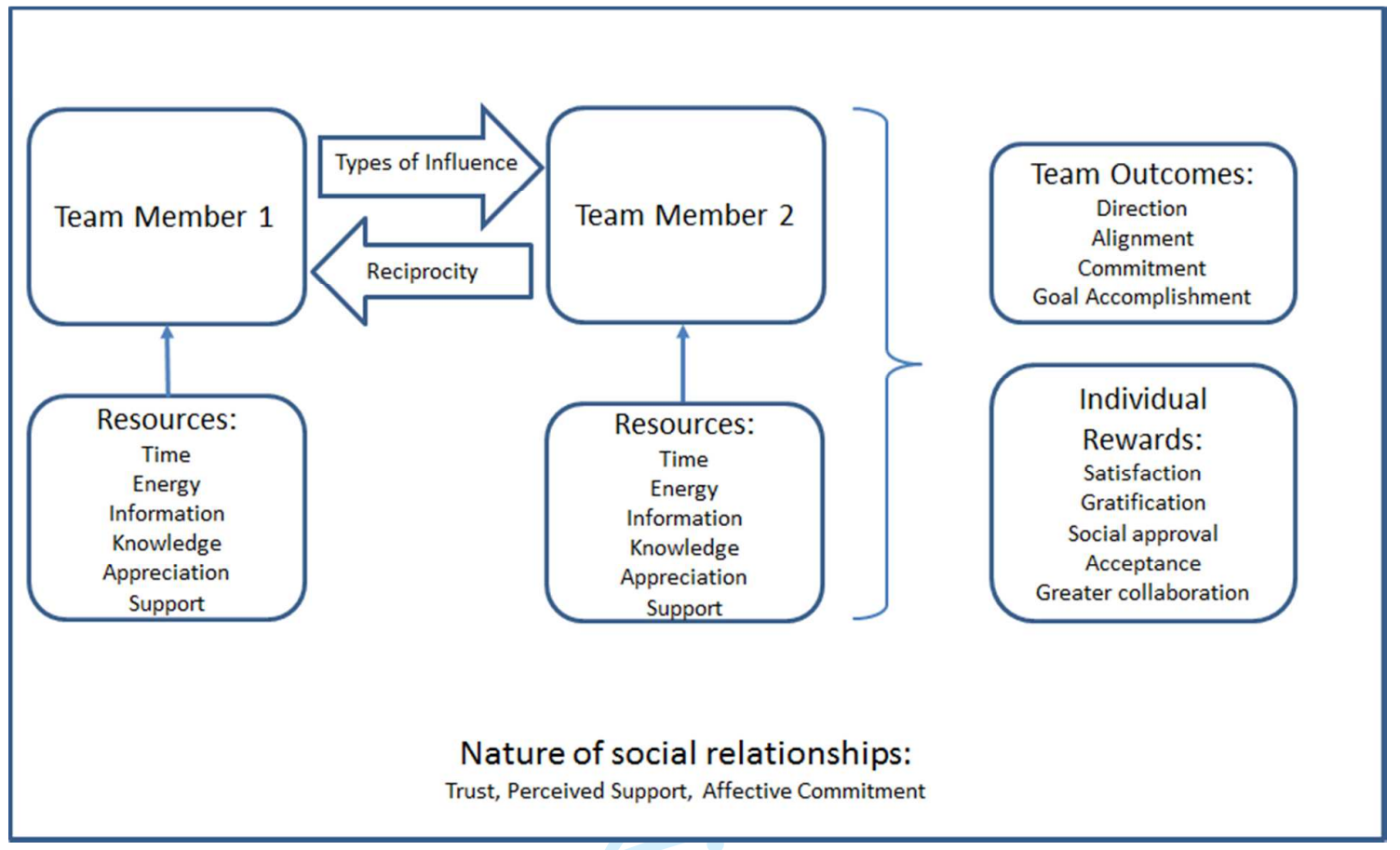

Fig. 2: Proposing a Future Research Agenda. 